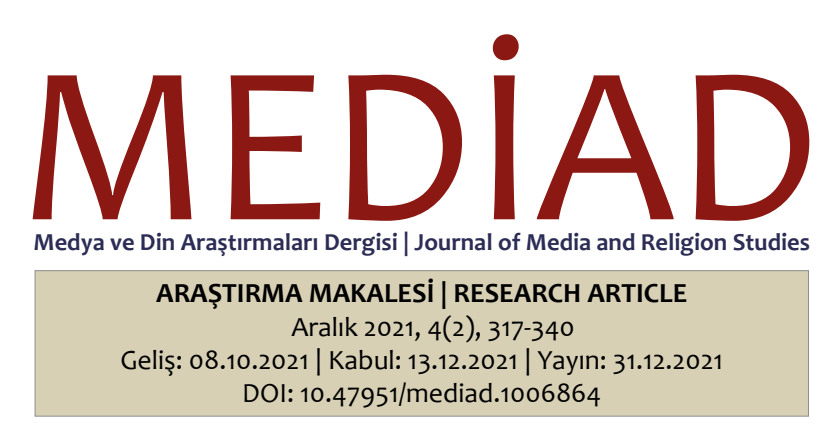

\title{
Diyanet İşleri Başkanlığı'nın Sosyal Medya Kullanımı: Başkanlık ve Birimleri Üzerine Bir Araştırma
}

\begin{abstract}
Yunus Emre SAYAN*
Öz

Bilgi çağı olarak nitelendirilen yeni dönemde bilgiye ulaşım ve iletişim araçları da zenginleşmiş, dijital araçlar ve sosyal medya öne çıkmıştır. Bu değişimde; bireyler, yeni iletişim araçlarına hızla uyum sağlarken; kurumlar farklılaşmakta, her alanda değişim yaşayan kurumlar yanında, konunun önemini henüz kavrayamayanlar da bulunmaktadır. Bu çalışmanın amacı, ülkemizde özellikle yaygın din eğitim-öğretimi bağlamında önemli bir misyonu olan Diyanet İşleri Başkanlığı'nın yeni medya karşısındaki durumunu, merkez ve taşra teșkilatlarında ( 81 il müftülüğü), kamuoyuna din hizmeti götürme konusunda görevini ifa ederken, hangi sosyal medya mecralarını kullandığını nicel ve nitel kapsamıla tespit etmektir. Özellikle 2019 Aralık ayında yaşanan Covid-19 pandemisi sonrası dünya genelindeki dijital dönüşüme paralel, ülkemizde de iletişim kanallarındaki değişimin Diyanet nezdinde nasıl gerçekleştiği ayrıca araştırmanın sorularındandır. Kurumun ve birimlerinin resmî web siteleri incelenerek hangi sosyal medya mecralarını kullandıkları tespit edilmiş, bu mecralarda öne çıkan birimler ve Facebook ve Twitter paylaşımları içerik analizine tabi tutulmuştur. Paylaşımların dini bilgilendirme, haber ve etkinlik ağırlıklı olduğu görülmüştür. Nicel veriler yanında kurumun online ve basılı yayınlarından sosyal medya konuları dokümantasyon yöntemi ile incelenmiştir. İl müftülüklerinin 54'ünün (\%67'sinin) en az bir sosyal medya mecrasında yer aldığı 27'sinin henüz bu mecraları kullanmadığı tespit edilmiştir. Çalışmada elde edilen veriler ışığında, merkez teşkilatına yönelik ve yeni başlayacak, henüz başlangıç düzeyinde olan diğer birimlere yönelik sosyal medya stratejileri ışığında önerilerde bulunulmuştur.
\end{abstract}

Anahtar Kelimeler: Din Eğitimi, Dinî iletişim, Sosyal Medya Araçları, Diyanet İşleri Başkanlığı, il-ilıçe Müftülükleri

\section{Social Media Usage Level of the Presidency of Religious Affairs: A Research in the Context of Central and Provincial Organizations}

\begin{abstract}
In the new era, which is characterized as the information age, the means of access to information and communication have also been enriched, and digital tools and social media have become prominent. In this change, individuals quickly adapt to new communication tools, but institutions react differently. While some institutions experience the change in every field, there are also those which have not yet grasped the importance of the subject. This study aims to analyze the situation of the Presidency of Religious Affairs, which has an important mission in our country, especially in the context of non-formal religious education, against the new media, and to analyze the use of social media while performing its duty to provide religious services to the public in central and provincial organizations, in quantitative and qualitative terms with the current situation and lastly to share the results of detailed research on this subject. In the light of the data obtained from this study, suggestions for central organization and for the units which are just starting out have been made in the light of social media strategies.
\end{abstract}

Keywords: Religious Education, Religious Communication, Social Media Tools, Presidency of Religious Affairs, Provincial-District Mufti

ATIF: Sayan, Y. E. (2021). Diyanet İşleri Başkanlığı'nın sosyal medya kullanımı: Başkanlık ve birimleri üzerine bir araştırma. Medya ve Din Araştırmaları Dergisi (MEDIAD), 4(2), s. 317-340. 


\section{Giriş}

Insanın tarih sahnesinde var olmasıyla başlayan iletişim, ağını genişleterek devam etmektedir. Zaman içinde hemcinsleri yanında dünyadaki muhtelif varlıklarla da iletişimi sağlayan insan, muhatabının farklılığı yanında geçmişten günümüze iletişim araçlarının da farklı türleriyle tanışmış, iletişim kanallarını geliştirmiştir. Günden güne yeni kazanımları ile bu kanallar, artarak, zenginleşerek, güçlenerek etki alanını da genişleterek ilerlemesini sürdürmektedir.

Insanlar arası iletişimi güçlendiren yeni nesil dijital iletişim araçları insanlar kadar kurumların da dikkatini çekmiş, kurumlar çok amaçı zengin dijital platformları ile hizmetlerini daha kolay, daha etkin, daha hızlı, daha erişilebilir ve interaktif yürütme imkânı bulmuşlardır.

Kurumların dijital medya kullanımları, kimisinde hızı, her alanı kapsayan çeşitlilikte seyrederken, hâlâ emekleme sürecinde olanların yanı sıra henüz bu alanları keşfedemeyenler de bulunmaktadır.

Sosyal medyayı kullanmak önemli olduğu kadar, nasıl kullanıldığı, kullanımın kamuoyu nezdinde karşılığı, alt birimlerin merkezi yapıyla eşgüdümlü olup olmadığı gibi konuların da zaman zaman araştırmaları gerekli kıldığı söylenebilir. Belirli periyotlarla yapılacak araştırmalarla kurumlar, eksiklerini tespit ederek yeni gelişmelere uyum sağlayarak, etkinliklerini artırarak sürdürebileceklerdir.

Türkiye'de yaygın din eğitim-öğretimi yapan ve muhtelif din hizmetlerinde bulunan Diyanet İşleri Başkanlığı (bundan sonra DiB olarak anılacaktır), üyelik, bağlııı, mensubiyet istememesiyle dinî gruplardan ayrılırken; aynı zamanda iletişim kuran devlet kurumlarından farklı, dinî iletişimle de farklılaşan özel yapısı ile dikkat çekmektedir. Hem kişilere yönelik hem kurumlar arası (dinî) iletişim bağlamında güncel iletişim araçlarıyla ilişkisi, güncel iletişim araçlarını kullanma düzeyinin bilimsel anlamda tespiti ve kurumsal iletişim planlamalarına ciddi veri sağlayacağı düşünülmektedir.

DiB Hizmetlerine Yönelim Durumlarının incelendiği bir araştırmaya katılan üniversite öğrencilerinin yaklaşık yarıı (\%44,5), DiB'in dini günler ve haftalarla ilgili etkinlik ve faaliyetlerinden haberdar olmadıklarını; katılımcıların \% 59,6 gibi önemli bir kısmı TRT Diyanet TV'yi hiç izlenmediğini bildirmiştir. Bu durum üniversite gençliğinin Diyanet tarafından düzenlenen faaliyet ve etkinliklerden yeterince haberdar olmadıklarını ortaya koyarken, TV kanalıın tanınırlığı ya da üniversite gençliğine hitap etme konusunda sıkıntılarının olduğu şeklinde yorumlanmıştır (Aşlamacı, 2016, s. 1579). Günümüz üniversite gençliğiyle dini iletişim kanallarının başında sosyal medya gelmektedir. Bu da, Diyanet'in bu noktadaki mevcut durumunun tespit edilmesini gerekli kılmaktadır.

Yaygın din eğitimi kurumlarından DiB ile ilgili teșkilatın Facebook ve Twitter hesapları (Aydın, 2016), Başkanlığın web sitesiyle ilgili içerik analizi (Çuhadar, 2015) ve dijital uygulamaları (Göksu, 2019) ile ilgili yapılan araştırmalar dışında çalışmaya rastlanmamıştır.

Teknolojideki baş döndürücü gelişmeler araştırmaların da belirli aralıklarla takibini, geliştirilerek devamını gerekli kılmakta, muhtemel gelişmeler üzerinden eksiklerin tespiti ve gerekli güncellemelerin yapılması beklenmektedir. Ayrıca din eğitimi açısından konunun ele alınması ayrı bir gerekliliktir. Özellikle Covid-19 pandemisi sonrası dinî iletişim bağlamında DiB'in merkez ve taşra teșkilatının sosyal medyayı kullanım durumu, hangi sosyal medya mecralarının kullanıldığı ve hangi içeriklere yer verildiği araştırılacaktır.

\section{Kuramsal Çerçeve}

\subsection{Sosyal Medya ve Din}

Sosyal medyanın tarihsel seyrini anlamak için internetin doğuşuna uzanmak gerekir. Veri, ses, müzik, metin, fotoğraf, görüntü biçiminde enformasyonun mikro işlemciler yardımıyla bilgisayar diline dönüştürülmesini ifade eden dijital teknoloji (Çuhadar, 2015, s. 176), internet ile yeni iletişim imkânı/ortamı oluşturmuş, kişilerin internet üzerinden birbirleriyle diyaloga girmesini ve paylaşımlarda bulunmasını sağlayan yeni bir medya sistemi ile sosyal medya adı verilen çift taraflı, eşzamanlı içerik ve bilgi paylaşımını sağlamıştır.

21. yüzyılda iletişim teknolojilerinin özellikle de internetin sosyal hayata nüfuz ederek bireylerin toplumsal yaşamının bir öznesi konumuna yükselmesi, dijital medyanın etkisini genişletmesi, interaktif iletişim/ etkileşim ortamının doğarak hızla gelişmesiyle yeni nesil iletişim araçları ve yeni platformlar yaygınlaşmaya başlamıştır.

Her platformun benzersiz avantajları vardır. Facebook, en yaygın olması hem mevcut çalışanlarla hem paydaşlarınızla, hem dinî konularda ilgili olanlarla profesyonel ağlar oluşturmada web sitenizle bağlantıları 
yönlendirmede öne çıkmaktadır. Kısa video ve fotoğraf paylaşımlarında ve daha genç kitlelere ulaşımda Instagram; kısa ve özlü mesajlarda, retweetlemede Twitter imkân sağlarken; kurumların özel bir video kanalı etrafında bir hayran tabanı oluşturmasında ve zengin e-öğrenme içerikleri sağlamada YouTube olanak tanımaktadır (Sayan, 2021, s. 437).

Dünyanın internet ve sosyal medya kullanım alışkanlıklarını tespit eden uluslararası kuruluşlardan ingiltere merkezli “We Are Social”'ın, "Digital 2021” (wearesocial, Ocak 2021), raporuna göre: “Dünya'da (16-64 yaş aralığındaki) insanlar gününün ortalama 6 saat 54 dakikasını internette geçirmektedir.

Raporda, 16-64 yaş arasındaki tüm internet kullanıcılarının interneti, en çok bilgi aramak (\%63,3), haber ve etkinliklerle ilgili süreci takip etmek (\%55,6), bir şeylerin nasıl yapılacağını araştırmak (\%52,1), \%42,8'in ise eğitim ve hedeflerle ilgili inceleme yapmak için kullandıkları ifade edilmiştir.

Sosyal medyayı en çok kullanan yaş grubu 25-34 olurken erkekler kadınlara oranla sosyal medyayı daha çok kullanmaktadır. Bir insan sosyal medyaya 13 yaşında üye olur ve 77 yaşına kadar yaşarsa hayatının 6 yılını sosyal medyada geçirmiş olacaktır.

2021 Nisan itibariyle (wearesocial, Nisan 2021), 7.85 milyar olan dünya nüfusunun \% 60,1’i (4.72 milyar insan) internet, \% 55.1'i (4.33 milyar) sosyal medya kullanmaktadır. 2021 yılı Ocak ayı itibariyle yayımlanan Türkiye raporuna göre (wearesocial, Ocak 2021 Turkey), 84.69 milyon nüfusa sahip Türkiye'de 65,8 milyon internet kullanıcısı bulunmaktadır. Bu değer toplam nüfusun \%78'ini olușturmaktadır. Türkiye'de 60 milyon (\%71) sosyal medya kullanıcısı mevcuttur. 16-64 yaş aralığındaki internet kullanıcıları günde ortalama 7 saat 57 dakikalarını internette geçirmektedir.

Genel olarak internet üzerinden yapılan aktivitelerin dağılımı incelendiğinde ise insanların gününün en çok zamanını, 3 saat 13 dakikasında TV izlemekle geçirirken, 2 saat 57 dakikasını sosyal medyada geçirdiği raporda ifade edilmektedir. Bu, sosyal medyanın günlük hayatta insanlar nazarındaki değerini ortaya koymaktadır.

Türkiye'de insanlar telefon uygulamaları üzerinden ayda; Instagram'da 19,7 saat, Whatsapp'ta 15 saat, TikTok'ta 14 saat, Facebook'ta 13,1 saat, Twitter'da 7,8 saat zaman harcamaktadırlar. Aylık aktif kullanıcı sayısı en fazla olan uygulamalar Whatsapp, Instagram ve Facebook'tur. Bu etkili bir iletişim için hangi mecraların öncelikle kullanılacağı noktasında önemli bir veri olabilir.

İnternetle başlayan ve gelişen yeni medyayla dinî bilgi, pratik ve topluluklar da sanal âleme taşınmış, çevrimdışı yaşam çevrimiçine aktarılmıştır. Dinler kendilerini temsil eden kitle iletişim araçları aracılığıyla vizyon ve misyonlarını kitlelere ulaştırma imkânı elde ederken (Menekşe, 2015, s. 152) sesleri yaşadıkları mekânla sınırlı kalan pek çok farklı düşünce ve yeni (dinî) anlayışlar, sanal ortamda kendine taraftar oluşturarak sanal/ dijital cemaat olarak yeni bir sanal dinî oluşum/topluluk kurmuşlardır. Bu alanda ilk araştırmalar da dinler hakkında genel bilgi, doküman sağlayan religion-online ile bir dinin kendi mensupları arasında etkileşimi sağlaması yanında yeni taraftar arayışlarında mensupları dışındaki kişilere erişimde bir tebliğ aracı olarak da kullanımı ifade eden online-religion ifadeleri kullanılmıştır. Özellikle kiliseler bu alanı çok iyi değerlendirmiş, dünya dillerinde dinî kitapları ücretsiz erişime açarak mensuplarını bilgilendirmeye, diğer insanları da kendi dinlerine kazandırmaya araç bilmişlerdir (îrk, 2015).

Batı'daki dinî kurum olarak kiliselerin bağlı olduğu Vatikan Konsülü, 1971'de Dünya iletişim Günü'nde yayınladığı Sosyal Iletişim Araçları Üzerine Pastoral Talimat Communio et Progressio, isimli talimatnamede yeni medyanın önemine şu sözlerle vurgu yapar: "Kilise bu medyayı, 'Tanrı'nın ilâhî takdirinde tasarlanmış araçlar, harika teknik icatlar', 'Tanrı'nın armağanları' olarak görüyor; tasarlayın, insanlığı kardeşlik içinde birleştirin ve böylece onların kurtuluş planında işbirliği yapmalarına yardımcı olun”... "Medyadaki sürekli gelişme, insanları günlük yaşamlarında giderek daha fazla kullanır kıııor; daha fazla insanı emrine veriyor. İnsanların yaşama ve düşünme biçimi iletişim araçları tarafından her zamankinden daha fazla etkileniyor." (Connor ve Ferrari-Toniolo, 1971, Madde: 2).

Dünyadaki dinî liderlerin ve dinî kurumların sosyal medyayı aktif kullanma eğiliminde olduğu görülmektedir. Örneğin Hristiyan dinî önderler, inancın, tam zamanlı bir faaliyet olduğunu ve sosyal medyanın günlük hayatımııın bir parçası olarak, din ile örtüşmesinin şaşırtıcı olmayacağı" anlayışıyla, sosyal medyanın, dinî cemaatlerin sadece haftalık özel ibadet günleri değil, hafta boyunca tweet atarak, sorular sorarak, kilise etkinliklerinin fotoğraflarını paylaşarak veya tartışmalara devam ederek vaazlarla aktif bir şekilde ilgilenmeleri için çok daha fazla alan sunduğu inancıyla bu alanda mensuplarını teşvik etmektedir (Lewis, 2017). 
Gerek gelişip büyümek gerekse mensuplarını diri tutmak için sosyal medyayı cankurtaran halatı olarak gören Kiliseler, mensuplarına dijital misyoner olmalarını, kendilerine özgü dijital misyoner stratejileri oluşturmalarını tavsiye ederken sosyal medyayı aktif kullanmaları için, Müslüman tebliğcilere de ilham kaynağı olabilecek bazı stratejiler (Tocci, 2018) sunmaktadır:

1. Her yerde olmaya çalıșmayın: Strateji anahtardır. Daha fazlası hiçin daha azla başlayarak, hedef kitlenize göre aşama aşama girin. Facebook, çeşitli yaş gruplarında güzelken, fotoğraf paylaşımı için Instagram harikadır. Twitter, kısa ve hızı bilgelikler için mükemmeldir.

2. Paylaşımınız kadar etkileşime de girin: Sosyal medyayı bir sohbet gibi düşünerek sadece siz konuşarak/paylaşarak değil; takipçilerinizle ve gönderilerinizle etkileşime girerek kullanılmalıdır.

3. Değerlerinizi koruyun: Sosyal medya, kendini olduğundan farklı gösteren, genellikle insanların ve kurumların en iyi hallerini sergiledikleri bir alandır. Bir cemaat olarak bu kalıbı kırarak sayfalarınızda dürüstlüğü tercih edin. Tüketicilerin sosyal medyada beklediği bazı değerler ve davranışlar şöyle; Dürüstlük \%86, Samimiyet/cana yakınlık $\% 83$, yardımseverlik \%78, eğlence $\% 72$, güncel \%43.

4. Hikâyelerle iletişim kurun: İnsanlarla iletişim kurmanın en akılda kalıcı ve etkili yollarından biri hikâyelerdir. Gönderinizi, hikâyeye dönüştürebilirsiniz.

5. Etkileșim sağlayacak paylașımlar yapın: Güzel alıntılar veya ayetler içeren özgün görseller hazırlanarak, insanların beğenip, paylaşabilecekleri içerikler paylaşıımalıdır. Sayfanın çok etkileşime sahip olması geniş dijital toplulukta daha çok insanın görmesini sağlayacaktır.

6. Daha geniş kitlelere ulaşmak için:

- Insanlara ilham veren moral verici sözler paylaşın veya sohbet oluşturacak eğlenceli sorular sorun. Her zaman kutsal metinler olması gerekmez; ancak, kilisenizin inancıyla uyumlu olması yeterlidir.

- Video sosyal medyada kraldır. Kilisenizdeki bir papazın akıllı telefonunda çekilen ve canlandırıcı bir kısa mesaj paylaşın!

- Olabildiğince düzenli paylaşın. Sosyal medyada duyuru, kilise etkinlikleri yanında, hayata dair, her seviyeden insanın hayatında karşılık bulacak paylaşımları önceleyin. Aktif sosyal medya gönderimi için sihirli bir sayı yoktur. Günde 1 Facebook durum güncellemesi, günde 3-10 Tweet, günde 1 Instagram yayını öncelikle yeterlidir.

7. Tartışmalara sessiz kalmayın, iyi davranışı gösterin: Sosyal medya, insanların rahat paylaştıkları bir alandır. Din konusunda herkesin söyleyecek sözü vardır. Olumsuz paylaşım yapanlara sevgi dolu, cana yakın bir içerik ve empati ile karşılık verin. Bu tavrı belirleyerek dünyaya, onların fikirlerine rağmen herkesle iletişim kurmaya hazır ve istekli olduğunuzu göstermiş olursunuz. Ve bu saygı, dağları hareket ettirebilir. Roma bir günde inşa edilmedi; bir takipçi oluşturmak zaman alır.

Kiliselerin sosyal medya konusunda yukarıdaki gibi stratejik adımlar attığı ve görevlilerinin bu stratejilere uygun çalışmalar yaptığı görülmektedir.

Yahudi Reform Birliği 2012'de Yahudi örgütlerinde görevli din eğitimcileri için “Sosyal Medya Politikaları Çalışma Kılavuzu” hazırlayarak bu konuda üyelerinin aktif yer almalarını sağlamayı hedeflemiştir (Appell, 2012).

\subsection{Dinî illetişim ve Yeni Medya}

İslam eğitim anlayışına göre insanın ilk iletişimi sözlü olarak yaratıcısıyla olmuş ( $\left.{ }^{\text {l-Arấf } 7 / 772}\right)$; sonrasında birbiri ile sürerek ve çevresiyle genişleyerek devam etmiştir. Zaman içinde kendi türleri dışında cinler (el-Arât 7/24-25, en-Nemı /78-39), kuşlar (en-Neml 27/16) gibi diğer dünya varlıklarıyla da iletişim sağlayan insan, muhatabının farklılığı yanında geçmişten günümüze iletişim araçlarının da farklı türleriyle tanışmış, iletişim kanallarını, etki alanlarını geliştirmiştir.

Allah'ın insanlar içerisinden görevlendirdiği resul ve nebilerle inanç, ibadet, muamelata dair kurallar koyan, hayata program çizen vahiy ile gönderilen mesajlar iletişimin bir boyutunu oluşturmuştur. Allah'ın insan ruhlarına hitabıyla sözlü iletişimle başlayan iletişim süreci, ilk insan ve ilk İslam Peygamberi Hz. Âdem'e ve İslam peygamberlerine verilen sahife ve kitaplarla, yazılı iletişimle yeni bir boyut kazanmış, i̇slam peygamberlerinden Hz. Süleyman'ın mesajını Hüdhüd'le Belkıs'a iletmesi (en-Nemı 27/20-28) ve İslam'ın son elçisi Hz. Muhammed'in (sav) mesajlarını iletmede mektubu kullanarak tebliğini sürdürmesiyle (en-Neysâbûrî, ts., s. 4326; Hamidullah, 1407, s. 135-36) zenginleşerek devam etmiştir.

Allah'ın stratejilerini de belirterek (en-Nisâ 4/53, Tahâ 20/44, eş̧̧uarâ 26/23-28, Âl-imrân 3/159, en-Nahl 16/125) istediği dini tebliğ emri (el-kasas 28/87, el-cin 72/23), dini iletişimin devamlılı̆̆ında büyük rol oynamış; illk halkasını peygamberlerin oluşturduğu bu yayılım sistemi, halkaya dâhil olan diğer inanmış insanların çabasıyla yaşamaya devam etmiş (Batar, 2020: s. 421), hem mensupları arasında hem de diğer insanları da kapsayacak genişlikte kıyamete kadar sürecek bir formatta devamlılığı sağlanmıştır. 
Hz. Peygamberin vefatından sonra bu iletişim sürecinin O’nun bıraktığı emanetlere ve yine insanlar arası iletişime dayalı olarak sürdüğü görülmektedir. Bu iletişim sürecinde dinî gelenek içerisinde gelișen, her türlü oluşum, kendi içinde, insanların dinle etkileşim kurmalarına, dinle ilgili tutumlarının oluşmasına vesile olan muhtelif iletişim ortamları oluşturmuştur (Batar, 2020, s. 419)

İnsanın hayatı anlamlandırması, kendisi, çevresi ve hayata dair ilk bilgiler bu anlamda iletişimle mümkün olmuş, yeryüzünde var olduğundan itibaren aile hayatı, siyaseti, ticareti, eğitimi vs. hayatına anlam katan tüm ilişkileri iletişime dayalı süreçlerle şekillenmiştir. Sonraki yıllarda farklı dünya görüşlerinin, günümüz bilimsel disiplinlerinin bakış açısı ile hayatta dini tefrik ve/veya tasnif eden bir bağlamda değerlendiren ayrımlarından, iletişim de payını almış, dinî iletişim başlığıyla iletişimin ayrı bir alanı olarak incelemelere konu olmuştur.

Dinî iletişim, muhtevasını dinî mesajların oluşturduğu dinî konularda yapılan iletişimden alır. İletişimin başlangıcını oluşturan türü olup, “yol göstermek, rehberlik etmek, bilgi vermek, istendik inanç, tutum ve davranış oluşturmak amacıyla Allah'ın peygamberler aracılığıla kullarına ilahi mesajlar göndermesi, onların da bu mesajlara olumlu-olumsuz geri bildirimde bulunmaları esasına dayanır" (Certel, 2008, s. 141). "Dinî içerikli bir duygunun, bilginin, haberin, düşünce veya tutumun bazı simgeler, semboller ve kanallar aracılığıyla kişiler, gruplar arasında ya da toplumsal düzeyde belirli ortamlarda paylaşıldığı dinamik bir süreçtir" (Batar, 2020, s. 424) Allah ile kulları arasında dikey iletişim olduğu gibi kullar/insanlar arası iletişimde yatay iletişim söz konusudur. ${ }^{1}$ Bu iletişim sözlü de sözsüz de olabilmektedir. Peygamberlerin toplumlarıyla ilişkileri, baştan sona “dinî iletişim süreci” olarak değerlendirilebilir. Zira peygamberlerden her biri Allah'tan vahiy yoluyla aldığı mesajı, sözlü ve/veya yazılı araçlarla insanlara iletmeye çalışmıştır. Peygamberlerin kavimleriyle olan iletişim ilişkilerinde, iletişimin bütün unsurlarının devrede olduğunu görebiliyoruz (Batar, 2020, s. 418)

Dinî iletişim, talim, terbiye, tebliğ, davet, beyan, tezkiye, zikir, vaaz, irşad vb. kavramları da kapsayan çok yönlü bir faaliyettir. Dinî iletişimde bulunanların görevi, sadece mesajı hedef kitleye iletmek değil, aynı zamanda iletilen mesajların anlaşılmasını ve benimsenmesini sağlamaktır (Koç, 2011, s. 13). Geçmişten günümüze, peygamberlerin hayata program çizen vahyi tebliğ faaliyetleri, dini yayma, yaşatma amaçlı her tür iletişimleri, bu konudaki eğitim-öğretim, irşâd çalışmaları yanında, her tür din mensubunun dinî propaganda ve misyonerlik faaliyetleri, dinî iletişim örnekleri olarak görülebilir.

Din hizmetleri, tebliğ ve irşat faaliyetleri toplumsal ve kültürel gerçeklerden bağımsız, tek biçimli, hep aynı tarzda sürüp giden statik bir bakış açısıyla ele alınıp sürdürülemez. Topluma ya da muhataplara sunulan dinî mesajların istenilen etkiyi meydana getirebilmesi için, her gün artan ve değişen iletişim araç, teknik ve yöntemlerini bilinçli olarak kullanmak, en az sunulan mesajın muhtevası kadar önem taşımaktadır (Hökelekli, 2006, s. 46).

Dinî eğitim - öğretim ve irşat hizmetleri yüz yüze başlamış, gelişen yazılı, sesli, görsel araçları da kullanarak geçmişten günümüze farklı araçlarla devam etmiştir. Illetişimin dört temel unsuru olan; kaynak - mesaj - araç/kanal ve alıcı'dan, araç/kanal kısmı, diğer iletişim araçları ve teknolojilerindeki gelişmelere paralel her daim gelişerek seyrini sürdürmüştür.

Illk matbaanın kurucusu Johannes Guttenberg'in (1398-1468) matbaasında ilk basılan kitap İncil olurken (Menekşe, 2015, s. 154), Hollandalı Christiaan Snouck Hurgronje'nin, 1885'te gittiği Hicaz'da, Mekke İmamı'nın okuduğu Kur'ân'ı, Edison tarafından icat edilen silindir şeklindeki fonografla alınan Dubai'de sergilenen ses kaydı, dünyadaki ilk dijital dinî kayıt olarak kabul edilebilir (Gur Media t.y.).

Dünya'da ilk radyonun, hakkında eleştiriler olsa da (O'Neal, 2006), 24 Aralık 1906'da bir Noel gecesi Kanadalı Anglikan bir papazın oğlu olan öğretmen kökenli Reginald Aubrey Fessenden (1866-1932) tarafından dinî bir ayinin ve İncil'den okunan ayetlerin/pasajların yayını ile başladığı kabul edilir (Curley, 2011) 1925'te ABD'de yayın yapan 600 radyonun 63'ünün kilise, dinî kurum ve/veya gurupların sahipliğinde olduğu belirtilmiştir. Avrupa'da ise ilk dinî radyo 1931'de yayına başlayan bugün 45 dilde yayını sürdüren Vatikan radyosudur. BBC, 1927'de radyoda, 1946'da TV'de ilk dinî yayını yapmıştır (Akyön, 2016, s. 44, 56, 60).

Nesilden nesile tevarüs eden dinî metinler, söz olarak başladığı yolculuğunda, önce harflerle yazılmış, baskı malzemelerinde basılmış, radyo yayınlarıyla evlere sesini duyurmuş, TV ile görüntüsünü seyirciye aktarmış, bilgisayar ile hem yazıyı hem sesi ve görüntüyü birleştirmiş, internetle daha zengin içerikle daha geniş kitlelere ulaşmış, nihayet mobil cihazlar ve sosyal medya ile zirveye ulaşmıştır (Vardi, 2012, s. 87).

Teknolojik yenilikleri, sosyal değişimleri takip eden dinî liderler, gruplar, topluluklar ve kurumlar, bu değişimin gerisinde kalmama mücadelesi vermişler, yeni medyanın sağladığı imkânlardan yararlanarak mesajlarını küresel ölçekte ulaştırmak amacıyla interaktif iletişim sağlayan elektronik ve dijital ortamın fırsatlarını 
değerlendirerek yeni atılımlar gerçekleștirmenin gayretinde olmuşlardır. Bu mayede, görsel, işitsel, sanal dinî yayınlar, sanal camiler, kiliseler, havralar, sanal fetvalar, sanal vaizler, sanal günah çıkarma gibi zengin yeni medya ürünleri görülmeye başlanmıştır (Menekşe, 2015, s. 155).

2017'de Hristiyan din eğitimcilerine yapılan bir araştırmada (Conrad 2018), Kutsal Kitap okuyucularının yarısından fazlasının İncil metinlerine internetle eriştiği (\% 55), Kiliselerin \% 70'inin personel ve konuklar için Wi-Fi hizmeti verdiği tespit edilmiştir (EJP, 2010).

PEW Araştırma Merkezi'nce yapılan ‘Dünya Dinlerinin Geleceği 2010-2050’ adlı değerlendirmeye göre, 2050'de dünya genelinde; genç nüfusu, Müslüman kadınların doğurganlık oranı ve Müslümanların daha çok çocuğa sahip olması gibi nedenlerden dolayı Müslüman nüfusunun \%73 artacağı, dünya nüfusunda dengeleri değiștireceği 2070'te en kalabalık dinî nüfus olacağı öngörülmektedir (Pew Research Center, 2015) Bunun yanı sıra ABD ve Avrupa'da Müslümanlara karşı negatif bir algı hüküm sürmektedir. Bu bilgiler ışığında büyüyen Müslüman kitleye ulaşmak ve güvenilir dinî bilgiyle bu kitleleri buluşturmak, İslamofobik unsurlara sağlıklı bir bilgilendirme son derece kritik bir görev olarak addedilebilir.

\subsection{Diyanet ve Dinî iletişim}

Türkiye'de dinî bilgilendirme, yaygın dinî eğitim-öğretim ve yönlendirme faaliyetleri anayasal bir kurum olan DiB üzerinden devlet eliyle gerçekleştirilmektedir. DiB'in tarihsel kökleri İslam'ın varlık bulmaya çalıştığı başlangıç süreçleriyle kolaylıkla ilişkilendirilebilse de onun kendine mahsus işleyişi Cumhuriyet’le birlikte başlamıştır (Subaşı, 2017, s. 224)

3 Mart 1924'te kurulan, kurumsal statüsü, özerkliği ve temsil sorunları zaman zaman tartışılan, bu tartışmalar yanında 1965'te 633 sayılı yasa ile 1982'de Anayasanın 136. maddesine eklenen yeni göreviyle kurumsal kimliğini sağlayan ve 2010'da 6002 sayılı kanun ile görev ve yetki alanını genişleten DiB, 2012 yılı Anayasa Mahkemesi kararı ile sistem içindeki önemini pekiştirmiş, son olarak doruk noktaya yaklaşarak, toplumsal meşruiyeti sağlamış, 2017 Anayasa değişikliklerine uyum çerçevesinde 703 sayılı KHK ile 9 Temmuz 2018 tarihinde Cumhurbaşkanlığı Teșkilatına bağlanmıştır. Böylece tarihi boyunca en büyük görev ve yetki alanına sahip olmuş, "Sosyal hayat ile teması artmış ve sosyal hayatı şekillendirme yönünde birçok yeni araca sahip olmuştur." (Aydın, 2019; Erdoğan, 2020). Günbegün misyon ve vizyonunu güçlendiren bir Cumhuriyet kurumu olarak Diyanet'in tarihi süreçte rolleri, kamuoyu nezdinde beklentiler değişse de, Diyanet her dönem kurumsal olarak farklılığını ortaya koymuş, kimi zaman "gözeten", kimi zaman "gözetleyen" olmuş, kimi zaman "sorulmadıkça konuşmamış", kimi zaman "konuşan Diyanet" olmuştur. Diyanet, herhangi bir şekilde kendi tercihini ortaya koyarken dolaylı ya da dolaysız bir yönlendirmeye maruz kalmaksızın hareket etme hassasiyeti içinde kendi kurumsallığını derinleştirmeye özen göstermiştir (Subaşı, 2017, s. 229-30).

Subaşı'na göre, “Diyanet'in Batılı kurumsal pratiklerin hatırlattığı anlamda bir kilise olmadığını bilmek gerekir. Görevi bir ortodoksi oluşturmak değildir.” "Diyanet'in temel misyonu, i̇slâm'ın genel geçer sınırlarının taciz edilmesini, çiğnenmesini önlemek, toplumu din konusunda doğru bilgilendirerek aydınlatmaktır" (Subaşı, 2005, s. 81). Her ne kadar "fazla beklentiye girilmemesini" ifade etse de, süreç içerisinde bir başka makalesinde yine Subaşı, kurumsal düzeyde Diyanet'in, başkanlarının tutumuna göre dönemsel cesur çalışmalarının da olabildiğine işaret etmekte; “Diyanet İşleri Başkanlığı'nın modern Cumhuriyet gereklilikleri içinde yerinin ne olduğu, neredeyse her on yılda bir değişen tasavvurlara bağlı olarak şekillendiğini", "sorumluluk üstlenen aktörün dinî ve entelektüel statüsü ile siyaset üstü tanımlaması içinde değerlendirilebilecek takva ve diğer meziyetlerinin" öne çıktığını belirtmektedir (Subaşı, 2017, s. 227).

Dinî iletişim ve yayın bağlamında DiB, 1935'te “Hak Dini Kur'ân Dili” isimli tefsir kitabıyla bașlayan basılı yayın çalışmalarını, 1956'da "Diyanet ilmi Dergi" ile süreli yayınla devam ettirerek, 1968'de "Diyanet Gazetesi", 1978'de "Diyanet Çocuk Dergisi”, 1991'de "Diyanet Aylık Dergi", 1999'da "Diyanet Avrupa Dergisi”, 2013'te “Âile Dergisi”, 2019'da “Arapça ilmi Dergi”, 2020'de gençlere yönelik "Geçerken Dergisi”, 4-6 yaş gurubuna yönelik "Diyanet Cim", 2021'de "Bayram Gazetesi” ile yayın ağını zenginleştirerek sürdürmekte, sahih dinî bilgiyi, yayınları yoluyla da yaygınlaştırma sadedinde kaynak eserlerden ilmi eserlere ve çocuk kitaplarına kadar çok sayıda eser yayımlamaktadır.

DiB'in, dinîiletişim amaçlı güncel her tür iletişim aracını kullanma gayretinde olduğu görülmektedir. Yayın hakkının TRT tekelinde olması sebebiyle ülkenin siyasi koşulları gereği müstakil radyo-tv yayıncılığı yakın döneme kadar gecikse de, günümüzde bu da gerçekleştirilmiştir. Türkiye'de ilk radyo yayını 1927'de başlamasına rağmen, dinî içerikli ilk yayın, 18 Ağustos 1950 Cuma günü sabahı itibariyle, TRT Ankara Radyosu'nda Kur'ân-ı Kerim yayınıyla başlamış, zamanla DiB mensuplarınca hazırlanan 10 dk.'lık "Dinî ve Ahlâkî Musâhabeler" adıy- 
la ilk dinî temalı programa yer verilmiş, 18 Nisan 1953'te haftada iki keze çıkarılmış, 1957'de mevlid kandili programı yapılmış, 1960'ta “radyoda sahur”, 1964'te “iftâr” programları yayınlanmıştır. 1993’te dinî cemaatlere bağlı özel dinî radyo yayınları başlamıștır. Radyoda kısa süreli dinî programlardan müstakil dinî yayın yapan radyoya uzun soluklu süreçte bugün çoğunluğu İslam içerikli bine yakın dinî radyo yayın yapmaktadır (Ak, 1992; Akyön, 2016). TÜiK verilerine göre 2002'den 2015'e radyo ve tv'lerde din ve ahlâk temalı yayın süresi \%150 artarak 429 bin 643 saate çıkmıştır (TÜiK, 2015). TRT ile DiB ortaklığında, 2013'te Diyanet Radyo, 2015'te Diyanet Kuran Radyo, 2017'de Hz. Peygamber'in hadislerini, sünnetlerini ve asr-ı saadeti dinleyiciye aktarmak için kurulan Diyanet Risalet Radyo yayın hayatına başlamıştır.

TRT'de ilk kez 31 Ocak 1968'de bașlayan TV yayınlarında, ilk dinî temalı program, 1974 Kadir gecesiyle başlamış, aynı yıl Hac canlı yayın olarak verilmiștir. 29 Ağustos 1975’te Ramazanda “iftara Doğru” adıyla ilk iftâr saati programı düzenlenmiştir. 1976-1977'li yıllarda Kur'ân Okuma yarışması ve Fetih konulu dinî muhtevalı programlara da yer verilmiştir. 80'lerin sonunda “Inanç dünyası” programı yayınlanmıştır. 2012'de TRT işbirliğinde yayın yapan “TRT Diyanet” kanalı, 1 Ocak 2019’da frekansı, kurumsal kimliği ve programları yenilenerek “Diyanet TV” ismiyle DïB yönetiminde müstakil bir TV kanalına dönüşmüştür (Çuhadar, 2019).

\section{Araștırmanın Metodolojisi}

\subsection{Araștırmanın Amacı, Önemi ve Problemi}

Bu araştırmanın amacı, DiB'in merkez ve taşra teşkilatının sosyal medya platformlarından nasıl yararlandığının ve dini iletişimde hangi sosyal medya platformlarını kullandığının tespit edilmesidir. Bu temel amaç çerçevesinde şu sorulara cevap aranmıştır:

a) DiB'in sosyal medya alanında yaptığı çalışmalar nelerdir?

b) DiB'in merkez ve taşra teşkilatı hangi sosyal medya araçlarını kullanmaktadır?

c) Dỉ'in merkez ve taşra teşkilatının kullandığı sosyal medya araçlarında takipçi sayıları ne kadardır?

d) DiB'in taşra teşkilatı, sosyal medya araçlarında hangi içeriklere yer vermektedir?

DiB'in hem kurumsal hem dini iletişim bağlamında yeni nesil iletişim araçlarını kullanarak personeli ve paydaşları yanında kamuoyu ile de sağlıklı bir iletişim kurması noktasında mevcut durumun tespiti ile kurumsal düzeyde bir çerçeve planın oluşturmasına çalışmanın katkı sağlayacağı değerlendirilmektedir.

\subsection{Araștırmanın Kapsamı ve Sınırlılıkları}

Araştırma DỉB'in Merkez teşkilatı ile taşra teşkilatının il müftülükleri ile sınırlıdır. Başkanlığın yurt dışı teşkilatları ile yurt içindeki Eğitim merkezleri, ilçe müftülükleri ve TDV kapsam dışında tutulmuştur. Dinî günler olarak üç ayları kapsayan süreç ve özellikle Ramazan ayı dinî heyecanın en yoğun, Diyanet'in kamuoyu ile dinî iletişiminin en fazla olduğu dönem olacağı düşünülerek 4 Şevval/Ramazan Bayramından sonraki ilk gün (16.05.2021 tarihinde) Merkez teşkilatının ve il müftülüklerinin sosyal medya hesapları araştırılmış, takipçi sayıları tespit edilmiştir. Takipçi sayılarının dinamik oluşu ve mevcut durumun tespiti sebebiyle bu tarihte elde edilen verilerle sınırlıdır. İl müftülüklerinin sosyal medya mecralarındaki paylaşımları 1443 Ramazan-Şevval aylarını kapsayan 13 Nisan - 10 Haziran 2021 dönemlerinde taranarak, içerik analizine tabi tutulmuştur. Makale sınırlarını aşmamak için içerik analizi, DiB'in taşra teşkilatının en çok takipçi sayısına sahip 10 müftülüğün ilk 5’inin Facebook ve Twitter kullanımlarıyla sınırlandırılmıştır.

\subsection{Yöntem}

Araştırmada dokümantasyon yöntemi ile DiB'in web sitesi üzerinden online tarama yapılarak sosyal medya ile ilgili içerik taraması yapılmıştır. Daha sonra betimsel tarama yöntemi ile 16.05.2021'de DiB merkez teşkilatı ile il müftülüklerinin resmî web siteleri incelenmiş, birimlerin resmî sosyal medya mecraları tespit edilerek 74 il müftülüğünün ilgili hesaplarına erişim sağlanmış; sosyal medya hesapları, mevcut takipçi sayıları ile paylaşım içerikleri taranmıştır. Nicel veriler tablolaştırılmıştır. Erişilemeyen yahut sahte hesap olma ihtimali sebebiyle resmî web sitelerinde linki/bilgisi verilmeyen 7 il müftülüğünün sosyal medya hesapları kapsam dışında tutulmuştur. Nicel verilerden elde edilen bilgiler doğrultusunda, örneklem yaklaşımlarından, daha fazla veri sağlayacağı düşünülerek amaçlı örnekleme yöntemi benimsenmiş (Creswell 2017, s. 267); en çok takipçi sayısına sahip il müftülüklerinin takipçi sayısı il nüfuslarına oranlanmış, ilk 5 müftülüğün iki aylık Facebook ve Twitter paylaşımları içerik analizine tabi tutulmuştur.

Patton (2014, s.167), nitel araştırmalarda inanılırlığın, titiz ve sıkı yöntemler, araştırmacının inanılırlığı ve nitel araştırmanın değerine olan inanç olmak üzere birbiriyle ilişkili ama farklı üç araştırma öğesine bağlı olduğunu belirtmiştir. Bu çalışmada elde edilen nitel bulguların iç ve dış geçerlilik ile güvenirlilik problemlerini aşmak için, literatürdeki benzer çalışmalar ve bunların araştırma metotları incelenmiştir. 


\subsection{Araștırma Verilerinin Toplanması, Analizi ve Yorumu}

Yayınlar taranmış, DiB'in sosyal medya konusunda kurumsal çalışmalar tespit edilmeye çalışılmıştır. Merkez teşkilatının ve il müftülüklerinin web siteleri incelenerek sosyal medya mecraları tespit edilmiştir. Buradan erişim sağlanarak ulaşılan sosyal medya kanalları incelenmiş, takipçi sayıları belirlenmiş, paylaşım içerikleri tespit edilmeye çalışılmıştır. DiB'in Başkanlık, merkez teşkilatı ve taşradaki bağlı birimlerinin sosyal medya mecralarındaki temsili, dağılım oranları oluşturulan tablolar doğrultusunda betimsel analize tabi tutulmuştur. Analiz ve değerlendirmeler yapılırken konuyla ilgili yapılan diğer araştırma verilerinden yararlanılmıştır. içerik analiz sürecinde, örnekleme alınan 5 il müftülüğünün Facebook ve Twitter sayfalarından elde edilen dokümanlardan bir çalışma taslağı hazırlanmış, içeriklerle ilgili izlenimler edinilmiştir. DiB'in faaliyet alanı dikkate alınarak en çok paylaşım yapılan kategoriler belirlenmiş, kodlamalar yapılmış, Facebook'ta 3, Twitter'da 5 ana tema belirlenmiştir. Her bir mecranın, her bir ana temasını oluşturan alt temalarla ana temalar detaylandırılmıştır. Diyarbakır İ Müftülüğü örneklem kapsamında olmasına rağmen, verilerin alındığı tarihlerde 3 günlük paylaşım dışında verilerine ulaşılamadığı için içerik analizi yapılırken, sıradaki il müftülüğü örnekleme dâhil edilmiştir.

\subsection{Araştırmanın Bulguları ve Yorum}

Bu bölümde DiB'in, araştırmaya konu olan birimlerinin sosyal medya üzerine çalışmaları temel başıklar hâlinde ele alınmıştır. illk olarak DiB'in sosyal medya çalışmalarında elde edilen bulgulara yer verilmiştir. İkinci olarak belirtilen tarihteki resmî sosyal medya verileri incelenmiş, nicel veriler, tablolaştırılarak ve alanyazın eşliğinde yorumlanarak sunulmuştur. Üçüncü olarak en çok takipçiye sahip ilk on müftülüğün nüfusa oranla karşılaştırıldığında ilk beşe giren müftülüklerin Facebook ve Twitter hesapları içerik analizine tabi tutularak bulgular paylaşılmıştır.

\subsubsection{Diyanet'in Sosyal Medya Çalıșmaları}

DíB'e anayasalar ve kuruluş kanununda verilen üç görevinden biri din konusunda toplumu aydınlatmaktır. DiB bu görevi yerine getirmek için gerekli tedbirleri almakla yükümlüdür. Başkanlığın sosyal medya konusunda özel bir birimi ve yönetmeliği bulunmamakla beraber, hizmet birimlerinden Din Hizmetleri Genel Müdürlüğü'nün görevleri arasında, "Yazilı, görsel, işitsel ve dijital medya vasıtasıyla toplumu din konusunda aydınlatma" ifadelerine de yer verilmektedir (DiB Kanun, 1965, Madde: 7/4).

DiB'in, 19 Ekim 2011'de Facebook, Kasım 2011'de Twitter, 6 Ocak 2012'de YouTube'da yer almaya başladığı görülmektedir. Türkiye'deki resmî kurumlar düzeyinde sosyal medyada ilk olarak Dışişleri Bakanlığı'nın 1 Mart 2010 tarihinde yer aldığı hatırlanırsa (Gülaslan, 2018, s. 208) DiB'in resmî kurumlar arasında sosyal medyanın gücünü erken fark eden kurumlardan olduğu söylenebilir.

Kurumların öncelikle kurumsal iletişim gereği sosyal medyada var olmaları önemlidir. Kurumsal kimliği, imajı, itibarı inşâ ve ihyâda, bu kazanımların devamlılığının sağlanmasında, kriz yönetiminde, hatırı sayılır katkıda bulunması yanında bilgilendirme, haber verme gibi halkla ilişkilerle ilgili faaliyetler için de yaygın ve etkin bir mecra olarak kurumsal iletişim, bilgi ve iletişim teknolojilerindeki hızlı gelişim ve dönüşümden etkilenmiş; kurumlar, bu etkileşim bağlamında seyri farklılık seyretse ve kontrol sorunu, taşıdığı muhtemel riskler, yeterli/nitelikli personel yokluğu vb. nedenlerle temkinli yaklaşsa da (Gümüş, 2018, s. 197) süreç içerisinde dijital dünyaya dâhil olmaya, merkezi ve yerel düzeyde sosyal medyayı doğru ve etkili kullanım için stratejiler geliştirmeye başlamıştır.

Türkiye'de internet kullanım oranının son beş yılda, 16-74 yaş grubundaki bireylerde 2016'daki \%61,2 oranından artarak, 2021 yılında \%82,6 olduğu, internet kullanıcılarının kamu kurumlarılyla iletişimlerinde son birkaç yılda artarak 2021'de yarıdan fazlasının $(\% 58,9)$ interneti kullandığı hatırlanırsa (TÜiK, 2021), bu durum kamu yönetimindeki internet uygulamalarının potansiyelini açıkça ortaya koymaktadır.

DiB'in, internet ve sosyal medya konusunda erken çalışma yapan kurumlardan biri olduğu görülmektedir. Diyanet Aylık Dergi'nin muhtelif sayılarında konunun ele alındığı tespit edilmiştir: ilk olarak 2008 Ağustos sayısı'nda "Din Üzerine Konuşma ve Medya" temasıyla ele alınmış; 2010 Ağustos sayısı, "çevrimiçi tehlike internet bağımlılı̆ı" temasıyla yayımlanmıştır. 2012 Ocak sayısında "Sosyal Ağlar ve iletişim Ahlakı" temasıyla, sosyal medyanın önemine ve tehlikelerine dikkat çekilirken, 2015 Ağustos "Medya ve Din", 2017 Mart sayısı, "Sanal Çağda Sahici Kalmak", 2020 Temmuz "Dijital Çağ ve Din İstismarı" ve 2021 Mayıs "Dijital Mecrada Ahlak" temasıyla DiB'in konuyla ilgili yayınlarını sürdürdüğü görülmektedir. 
DiB, 18 Ocak 2012 tarihinde, "Diyanet, sosyal medyada” başlığıyla kamuoyunu bilgilendirmiş "hizmet ve faaliyetlerini daha geniş toplum kesimlerine ulaştırabilmek amacıyla sosyal medyayı etkin olarak kullanmaya başladı." ifadelerine yer vererek aşağıda belirtilen resmî dört sosyal medya hesabının adresini paylaşmıştır (DiB Haber, 2012).

Dönemin Diyanet İşleri Başkanı, Twitter hesabından; "her Cuma günü takipçileriyle Hazreti Peygamberin hikmetli sözlerinden bazı kesitler paylaşacağını" duyurmuş, Hz. Peygamberin "Güzel söz sadakadır, Allah'ın kullarına selam vermeniz sadakadır, Kardeşinizin yüzüne tebessüm etmeniz sadakadır.” hadis-i şerifini de ilk olarak paylaşmıştır (DiB Haber1, 2012).

25-28 Kasım 2019'da gerçekleşen VI. Din Şûrası'nda bir komisyonda, "Sosyal Medya ve Dinin Sunumu" müzakere edilmiştir.

Başkanlığın 2019-2023 Misyonu; "islam dininin inanç, ibadet ve ahlâk esaslarıyla ilgili işleri yürütmek, sahih dinî bilgi ile toplumu aydınlatmak ve ibadet yerlerini yönetmek" vurgusunu yapmaktadır. Diyanet İşleri Başkanlığının vizyonu ise, "islam dini ile ilgili her konuda güvenilen ve referans alınan, insanlığın barış ve huzuruna katkı sağlayan bir kurum olmak" şeklinde belirlenmiştir (DiB SP, 2020). Bu görevleri gerçekleştirmede araç olması bakımından, güncellenen Stratejik Planda sosyal medya ile ilgili; "Bașkanlığın basılı yayınlar yanında TV, Radyo ve sosyal medya yayıncılı̆̆ı imkânının olması" tespitlerine yer verilmiş; "Sahih dinî bilginin günümüz teknolojik imkânlarından yararlanarak toplumun tüm kesimlerine etkili şekilde sunulması" intiyaçlar arasında gösterilmiştir. "Dinî bilgiyi hedef kitleye uyarlayarak iletim ve erişim kanallarını geliştirmek"(H3.2) hedefine ulaşmak için, "Diyanet TV/radyoları ve sosyal medya hesaplarının izleyici, dinleyici ve takipçi sayılarını artırmak." stratejisine yer verilmiş, performans göstergeleri arasında (PG3.2.3) sosyal medyadaki paylaşımların çeşitlendirilip artııılması yer almıştır (DiB SP, 2020)

Diyanet İşleri Başkanı Prof. Dr. Ali Erbaş, Ramazan ayında, Ankara'da çeşitli üniversitelerde okuyan gençlerle buluşmasında, "Dünyadan haberdar olma, iyiliği yeryüzünün her noktasına ulaştırma gibi sosyal medyayı hayırlı yolda kullanmalıyız" mesajını vermiştir (DiB Haber2, 2019).

17.01.2020 tarihli Cuma hutbesi, "Teknoloji Bağımlıı̆̆ı ve Sosyal Medya Ahlakı” konulu (DiB Hutbe, 2020) olup, sosyal medya konusunda kamuoyu bilinçlendirilmesi amaçlanmıştır.

2020'de ‘Akışkan Zamanlarda “Değer”li Yaşamak', ‘Dijital Çağ’da Iletişim Ahlakı’ ve ‘Sosyal Medya Ahlakı' isimli eserler yayımlanmıştır.

DiB'in 15.12.2020 tarih ve E.847444 sayılı Başkanlık onayı ile yürürlüğge giren "Diyanet İşleri Başkanlığı Din Hizmetleri Genel Müdürlüğü Uygulama Genelgesi”"nin (DiB Genelge, 2020), "Sosyal Medya Araçları Vasıtasıyla İrşat Hizmetleri” başlığıyla 42. maddesinde, sosyal medya konusunda önemli stratejilere yer verildiği görülmektedir. Genelge ile sosyal medyada yürütülecek hizmetler için yetkilendirilen "il/ilçe irşad kurulları" marifetiyle gerekli planlamanın yapılması, "Teknik bilgiye sahip bir personelin, sosyal medya teknik sorumlusu olarak belirlenmesi” istenmiş; sosyal medya paylaşımlarında "paylaşım zamanı, paylaşılacak konular, paylaşım üslubu, paylaşılacak ürünler" vb. konularda detaylı stratejilere değinilmiştir. "Vaaz ve irşat hizmetlerinin kurumsal sosyal medya hesapları üzerinden yürütülmesi, haftada en az bir vaazın, belirlenen bir camide okunan hutbenin müftülük sosyal medya hesaplarından yayımlanabileceği" belirtilmiștir. "Sosyal medya araçlarının özellikleri dikkate alınarak toplumun çeşitli kesimlerine yönelik farklı formatlarda dinî içerikli yayınlar hazırlanması ve sosyal medya mecralarında paylaşılması" da genelgede dikkat çeken ifadelerdendir.

9 madde, 16 alt maddede konunun öz bir şekilde ele alındığı görülmektedir. Genelgede belirtilen iş ve işlemlerle ilgili takibin yapılmasıyla sosyal medyanın etkin kullanımının söz konusu olacağı değerlendirilmektedir.

Başkan Prof. Dr. Ali Erbaş, “Haydi Türkiye Evden Kur’an Öğrenmeye” sloganıyla sosyal medya hesaplarından video mesaj yayınlayarak; vatandaşları uzaktan eğitimle gerçekleştirilen “Kur’an-ı Kerim Öğretim Programı"na katılmaya davet etmiştir (DiB Haber3, 2020).

2020 yılı içinde, Sosyal medya paylaşımları kapsamında ise DiB sosyal medya hesaplarından toplam 536 içerik paylaşımı gerçekleştirilirken Başkan Erbaş'ın sosyal medya hesaplarından toplam 377 içerik paylaşımı yapılmıştır.

DiB, “2021 Yılı Performans Programı” kapsamımda, 'Temel Politika ve Öncelikler’ arasında, Diyanet TV/ radyoları ve sosyal medya hesaplarının izleyici, dinleyici ve takipçi sayılarını artırmayı da hedef olarak belirlemiştir (DiB 2021, Performans Programı, s. 30). 
Katıldığı bir özel TV'de Başkan Erbaș'ın; “Sosyal medyada biri sizinle hiç alakalı olmayan bir konuyu sanki siz söylemişsiniz gibi bir tiwit atıyor, o yalanı binlerce kişi beğeniyor, paylaşıyor. Bu, şifa aramamız gereken ne kadar kötü bir hastalık. Ne olur, kardeşlerimiz buna dikkat etsinler”(DỉB Haber4, 2021) uyarısında bulunduğu tespit edilmiştir.

28-30 Mayıs 2021'de düzenlenen 8. Dinî Yayınlar Kongresi, “Dijital Yayıncılık” temasıyla yapılmıștır.

\subsubsection{Diyanet Merkez ve Taşra Teşkilatı Sosyal Medya Kullanım Durumları ve Takipçi Sayıları}

Dỉ’in Merkez Teşkilatında Başkanlık basın birimi ile Hac ve Umre Hizmetleri Genel Müdürlüğü dışında diğer birimlerinin sosyal medya kullanmadıkları tespit edilmiştir.

Tablo 1. DiB Merkez Teşkilatı Sosyal Medya Kullanım Bilgileri

\begin{tabular}{|c|l|c|c|c|c|c|c|}
\hline \multirow{2}{*}{} & \multirow{2}{*}{ Merkez Teşkilatı } & \multicolumn{6}{|c|}{ Sosyal Medya Mecrâları ve Takipçi Sayıları } \\
\cline { 2 - 8 } & Facebook & Twitter & Instagram & YouTube & Telegram & TOPLAM \\
\hline \multirow{2}{*}{1} & $\begin{array}{l}\text { Başkanlık (diyanet- } \\
\text { basin) }\end{array}$ & 669906 & 316800 & - & 17400 & 8055 & 1.012 .161 \\
\cline { 2 - 8 } & $\begin{array}{l}\text { Dỉ Ali Erbaş (Baş- } \\
\text { kan, kişisel) }\end{array}$ & 182930 & 402500 & 297000 & - & - & 882.430 \\
\hline 2 & $\begin{array}{l}\text { Hac ve Umre } \\
\text { Hizmetleri Genel } \\
\text { Müdürlüğüu }\end{array}$ & 4559 & 2145 & 1083 & 1000 & - & 8.787 \\
\hline
\end{tabular}

Tablo 1'de de görüldüğü üzere, Başkanlık, diyanetbasin ismiyle dört sosyal medya mecrasında (Facebook, Twitter, YouTube ve Telegram) yer almaktadır. Başkanlığa ait sosyal medya mecralarında, Başkan'a ait paylaşımlar öne çıkarken, günün anlam ve önemine binaen ayet, hadis, dua paylaşımları, yardım kampanyası bilgileri, Cuma hutbeleri, Cuma ve cenaze namazları videoları ile Başkanlığın görev alanına yönelik geniş kapsamlı etkinliklerle ilgili paylaşımlara ve Başkan'ın gündeme dair konuşmalarına, etkinliklerine yer verildiği tespit edilmiştir.

Merkez Teşkilatında 14 birim yer alırken, ana hizmet birimlerinden sadece Hac ve Umre Hizmetleri Genel Müdürlügüu'nün sosyal medya hesapları (Facebook, Twitter, Instagram ve YouTube) bulunmaktadır. Hac ve Umre Hizmetleri Genel Müdürlüğü hesaplarında görev alanıyla ilgili ayet, hadis, dua paylaşımları, kutsal mekanlardan görseller, online yapılan ilk uluslar arası Hac Sempozyumu içeriklerine yer verildiği tespit edilmiştir.

Merkez Teşkilatının bir kısmının görev alanıyla ilgili sosyal medya hesabına ihtiyaç duymadığı düşünülse de icracı olarak düşünülebilecek ana hizmet birimlerinden olan Genel Müdürlükler, sosyal medya mecrasında yer alması beklenilen birimlerdir.

Tablo 2 ile karşılaştırıldığında en popüler hesaplar Başkanlığa aittir. Başkanlık, gerek toplamda gerekse ortak kullanılan her bir mecrada birimlerine göre en çok takipçi sayısına sahiptir. Merkezi kullanım avantajı yanında taşradaki birimlerinin de web sitelerinde ve kendi sosyal medya mecralarında Başkanlığın linklerini vermesi popülerlik sebebi olarak algılanabilir.

Tablo 2. DiB Taşra Teşkilatı: il Müftülükleri Sosyal Medya Kullanım Bilgileri

\begin{tabular}{|c|l|c|c|c|c|c|}
\hline \multirow{2}{*}{ Plaka } & \multirow{2}{*}{ Müftülük Adı } & \multicolumn{5}{|c|}{ TAKiPçi SAYILARI } \\
\cline { 3 - 7 } & & Facebook & Twitter & Instagram & YouTube & TOPLAM \\
\hline 1 & Adana İ Müftülüğü & 4723 & 307 & - & - & 5030 \\
\hline 2 & $\begin{array}{l}\text { Adıyaman II Müf- } \\
\text { tülüğü }\end{array}$ & - & - & - & 91 & 91 \\
\hline 3 & $\begin{array}{l}\text { Afyonkarahisar İl } \\
\text { Müftülüğü }\end{array}$ & - & - & - & - & - \\
\hline 4 & Ağrı İ Müftülüğü & 723 & 355 & 855 & 96 & 2029 \\
\hline 5 & $\begin{array}{l}\text { Amasya il Müftü- } \\
\text { lüğü }\end{array}$ & 4308 & 416 & 1204 & 234 & 6162 \\
\hline 6 & Ankara III Müftülüğüü & 9302 & 399 & 1627 & - & 11328 \\
\hline
\end{tabular}




\begin{tabular}{|c|c|c|c|c|c|c|}
\hline 7 & $\begin{array}{l}\text { Antalya il } \\
\text { Müftülüğü }\end{array}$ & 11138 & 543 & - & - & 11681 \\
\hline 8 & Artvin il Müftülüğü & - & - & - & - & - \\
\hline 9 & Aydın il Müftülüğü & - & - & - & - & - \\
\hline 10 & $\begin{array}{l}\text { Balıkesir il Müftü- } \\
\text { lüğü }\end{array}$ & 8414 & - & - & - & 8414 \\
\hline 11 & Bilecik il Müftülüğü & - & - & - & - & - \\
\hline 12 & Bingöl îl Müftülüğü & - & 517 & - & - & 517 \\
\hline 13 & Bitlis İl Müftülüğü & - & - & - & - & - \\
\hline 14 & Bolu ill Müftülüğü & 2316 & - & - & - & 2316 \\
\hline 15 & Burdur il Müftülüğü & - & - & - & - & - \\
\hline 16 & Bursa II Müftülüğü & 13078 & 1054 & - & - & 14132 \\
\hline 17 & $\begin{array}{l}\text { Çanakkale il } \\
\text { Müftülüğüü }\end{array}$ & 2195 & 385 & 1470 & 137 & 4187 \\
\hline 18 & Çankırı il Müftülüğü & - & - & - & - & - \\
\hline 19 & Çorum il Müftülüğü & 8113 & 101 & 499 & 12 & 8725 \\
\hline 20 & Denizli il Müftülüğü & - & - & - & - & - \\
\hline 21 & $\begin{array}{l}\text { Diyarbakır İ Müf- } \\
\text { tülüğüu }\end{array}$ & 13093 & 526 & 1736 & 957 & 16312 \\
\hline 22 & Edirne IIl Müftülüğü & 2944 & - & 1228 & - & 4172 \\
\hline 23 & Elazığ ilı Müftülüğü & 3451 & 158 & 1241 & 442 & 5292 \\
\hline 24 & $\begin{array}{l}\text { Erzincan il Müftü- } \\
\text { lüğü }\end{array}$ & 11676 & - & - & 539 & 12215 \\
\hline 25 & $\begin{array}{l}\text { Erzurum il Müftü- } \\
\text { lüğü }\end{array}$ & 8633 & 612 & 1621 & 285 & 11151 \\
\hline 26 & $\begin{array}{l}\text { Eskişehir III Müftü- } \\
\text { lüğü }\end{array}$ & 11898 & 557 & - & - & 12455 \\
\hline 27 & $\begin{array}{l}\text { Gaziantep il Müf- } \\
\text { tülüğüu }\end{array}$ & 5971 & - & - & - & 5971 \\
\hline 28 & $\begin{array}{l}\text { Giresun il Müftü- } \\
\text { lüğü }\end{array}$ & 2489 & 504 & 1955 & 582 & 5530 \\
\hline 29 & $\begin{array}{l}\text { Gümüșhane il Müf- } \\
\text { tülüğü }\end{array}$ & - & - & - & - & - \\
\hline 30 & $\begin{array}{l}\text { Hakkâri İl Müftü- } \\
\text { lüğü }\end{array}$ & - & - & - & - & - \\
\hline 31 & Hatay il Müftülüğü & - & - & - & - & - \\
\hline 32 & Isparta il Müftülüğü & - & - & - & - & - \\
\hline 33 & Mersin II Müftülüğü & 5028 & - & - & - & 5028 \\
\hline 34 & $\begin{array}{l}\text { İstanbul il } \\
\text { Müftülüğü }\end{array}$ & 19932 & 2902 & 6473 & 10900 & 40207 \\
\hline 35 & İzmir İl Müftülüğü & 5015 & - & - & 256 & 5271 \\
\hline 36 & Kars ill Müftülüğü & - & - & - & - & - \\
\hline 37 & $\begin{array}{l}\text { Kastamonu ill } \\
\text { Müftülüğü }\end{array}$ & 3182 & 455 & 1365 & 340 & 5342 \\
\hline 38 & $\begin{array}{l}\text { Kayseri İl Müftü- } \\
\text { lüğüu }\end{array}$ & - & - & - & - & - \\
\hline 39 & $\begin{array}{l}\text { Kırklareli ill Müftü- } \\
\text { lüğü }\end{array}$ & - & - & - & - & - \\
\hline 40 & $\begin{array}{l}\text { Kırşehir il Müftü- } \\
\text { lüğüü }\end{array}$ & - & - & - & - & - \\
\hline
\end{tabular}




\begin{tabular}{|c|c|c|c|c|c|c|}
\hline 41 & $\begin{array}{l}\text { Kocaeli ill Müftü- } \\
\text { lüğü }\end{array}$ & 3491 & - & - & - & 3491 \\
\hline 42 & Konya il Müftülüğü & 17562 & 919 & 4216 & 6.660 & 29357 \\
\hline 43 & $\begin{array}{l}\text { Kütahya IIl Müftü- } \\
\text { lüğü }\end{array}$ & 7499 & 764 & - & 2190 & 10453 \\
\hline 44 & $\begin{array}{l}\text { Malatya il Müftü- } \\
\text { lüğü }\end{array}$ & - & - & - & - & - \\
\hline 45 & $\begin{array}{l}\text { Manisa İl Müftü- } \\
\text { lüğü }\end{array}$ & - & - & - & - & - \\
\hline 46 & $\begin{array}{l}\text { Kahramanmaraş İl } \\
\text { Müftülüğüü }\end{array}$ & 2136 & - & - & - & 2136 \\
\hline 47 & $\begin{array}{l}\text { Mardin IIl Müftü- } \\
\text { lüğü }\end{array}$ & 1519 & 294 & - & 1050 & 2863 \\
\hline 48 & Muğla ill Müftülüğü & 1609 & - & - & - & 1609 \\
\hline 49 & Muş il Müftülüğü & 2560 & - & - & - & 2560 \\
\hline 50 & $\begin{array}{l}\text { Nevşehir İl Müftü- } \\
\text { lüğü }\end{array}$ & - & - & - & 302 & 302 \\
\hline 51 & Niğde ill Müftülüğü & 1605 & 448 & 1671 & 161 & 3885 \\
\hline 52 & Ordu III Müftülüğü & 6320 & 673 & - & 1310 & 8303 \\
\hline 53 & Rize İl Müftülüğü & 11396 & 1998 & 1420 & 951 & 15765 \\
\hline 54 & $\begin{array}{l}\text { Sakarya ill Müftü- } \\
\text { lüğü }\end{array}$ & 2778 & 719 & - & - & 3497 \\
\hline 55 & $\begin{array}{l}\text { Samsun il Müftü- } \\
\text { lüğü }\end{array}$ & 22422 & 516 & 1955 & - & 24893 \\
\hline 56 & Siirt İl Müftülüğü & 1177 & 407 & 955 & - & 2539 \\
\hline 57 & Sinop il Müftülüğg̈ü & - & 628 & - & - & 628 \\
\hline 58 & Sivas ill Müftülüğü & - & - & - & - & - \\
\hline 59 & $\begin{array}{l}\text { Tekirdağ il Müftü- } \\
\text { lüğü }\end{array}$ & - & - & - & - & - \\
\hline 60 & Tokat İl Müftülüğü & 5596 & 507 & - & - & 6103 \\
\hline 61 & $\begin{array}{l}\text { Trabzon ill Müftü- } \\
\text { lüğü }\end{array}$ & 8594 & 223 & - & - & 8817 \\
\hline 62 & Tunceli İl Müftülüğü & 2626 & - & - & - & 2626 \\
\hline 63 & $\begin{array}{l}\text { Şanlıurfa İl } \\
\text { Müftülüğü }\end{array}$ & 5480 & 740 & 1861 & 225 & 8306 \\
\hline 64 & Uşak IIl Müftülüğü & - & - & - & - & - \\
\hline 65 & Van II Müftülüğg̈ü & 3241 & 785 & - & - & 4026 \\
\hline 66 & Yozgat Ill Müftülüğü & 3807 & - & 1053 & 1.430 & 6290 \\
\hline 67 & $\begin{array}{l}\text { Zonguldak II Müf- } \\
\text { tülüğü }\end{array}$ & 2676 & 594 & 3164 & 159 & 6593 \\
\hline 68 & $\begin{array}{l}\text { Aksaray il Müftü- } \\
\text { lüğü }\end{array}$ & 2899 & 180 & 814 & 1530 & 5423 \\
\hline 69 & $\begin{array}{l}\text { Bayburt il Müftü- } \\
\text { lüğü }\end{array}$ & - & - & - & - & - \\
\hline 70 & $\begin{array}{l}\text { Karaman İl Müftü- } \\
\text { lüğü }\end{array}$ & 2247 & 134 & 1135 & 105 & 3621 \\
\hline 71 & $\begin{array}{l}\text { Kırıkkale İl Müftü- } \\
\text { lüğü }\end{array}$ & 2514 & 129 & - & - & 2643 \\
\hline 72 & $\begin{array}{l}\text { Batman il Müftü- } \\
\text { lüğü }\end{array}$ & 1724 & 732 & - & - & 2456 \\
\hline
\end{tabular}




\begin{tabular}{|c|l|c|c|c|c|c|}
\hline 73 & Şırnak il Müftülüğü & - & - & - & - & - \\
\hline 74 & Bartın il Müftülüğü & 4212 & 147 & - & 379 & 4738 \\
\hline 75 & $\begin{array}{l}\text { Ardahan II Müftü- } \\
\text { lüğü }\end{array}$ & - & - & - & - & - \\
\hline 76 & Iğdır il Müftülüğü & - & - & - & - & - \\
\hline 77 & Yalova il Müftülüğg̈ü & - & - & - & - & - \\
\hline 78 & $\begin{array}{l}\text { Karabük il Müftü- } \\
\text { lüğü }\end{array}$ & - & - & - & - & - \\
\hline 79 & Kilis il Müftülüğü & 3805 & - & - & - & 3805 \\
\hline 80 & $\begin{array}{l}\text { Osmaniye il Müf- } \\
\text { tülüğü }\end{array}$ & 2771 & 420 & - & 304 & 3495 \\
\hline 81 & Düzce il Müftülüğü & - & 509 & 1543 & - & 2052 \\
\hline
\end{tabular}

Tablo 2'de de görüldüğü üzere, Türkiye'deki il müftülüklerinin sosyal medya kullanımlarıyla ilgili elde edilen verilere göre, 81 il Müftülüğünden 54'ü (\%67) en az bir sosyal medya mecrasında yer alırken, bunların; 17'si (\%21) 4 sosyal medya mecrasında aynı anda yer almakta, 9'u (\%11) 3'ünde, 14'ü(\%17) 2'sinde, 14'ü sadece bir sosyal medya mecrasında yer almaktadır. 27 il Müftülüğü (\%33) ise sosyal medya kullanımını hâlâ tercih etmemektedir. 2016 yılında yapılan benzer bir araştırmadaki(Aydın, 2016: s. 207) verilerde, 21 ilı Müftülüğünün sosyal medyada olduğu düşünülürse, beș yıl sonra il müftülüklerinde ciddi bir artış olduğu; ayrıca, sosyal medya mecralarını zenginleştirdikleri söylenebilir.

II müftülükleri dünyadaki kullanıma paralel, en çok Facebook'u (49 il Müftülüğü, \%60) tercih ederken, bunu sırayla, Twitter (38 il Müftülüğü \%47); YouTube (27 il Müftülüğü, \%33) ve Instagram (23 il Müftülüğü, \%28) takip etmektedir. Diğer sosyal medya mecralarına pek ilgi gösterilmemiştir.

2017'de Hristiyan din görevlilerine yönelik yapılan bir araştırmada (Conrad 2018), kiliselerin \% 85’inin Facebook, \% 15 sinin Twitter ve Instagram kullandığı, kiliselerin \% 62 ssinin cemaatleri dışındaki kişilerle bağlantı kurmak için sosyal ağ kullandığı tespit edilmiştir.

Yahudi din görevlilerine yapılan bir araştırmada ise, sinagog görevlilerinin \%63'ü, kurumsal web siteleri olduğunu, sitelerinde temel düzeyde bilgiler sunulduğunu, etkileșim olmadığını belirtmiş; bunların 2/3’ü sinagog Facebook hesabının varlığını bildirirken, 4/5'ten fazlası Twitter'ı kullanmadıklarını söylemiștir. \%59'u kullanım zorluğundan ve en iyi şekilde nasıl kullanılacağını bilmediğinden yakınırken, \%86 personel ve ilgilenecek gönüllü bulamadıklarını ifade etmişlerdir (EJP, 2010) Bu sonuçlarla değerlendirildiğinde il müftülükleri, en az bir sosyal medya mecrası kullanımıyla (\%67), diğer dinî kurumlarla yakın orana sahip olsa da Facebook kullanımında yeterli görünmezken, Twitter'da ve Instagram'da ise daha fazla kullanımla öne çıkmaktadır.

İ müftülüklerinin en çok Facebook'u tercih etmesi ile mensupları olan din görevlilerinin de sosyal medyada en çok Facebook tercih ettiği bulgularıyla benzerlik arz etmektedir (Aydın ve Eken, 2014, s. 393).

Tablo 2'de bazı müftülüklerin web sitelerinde sosyal medya logoları olmasına rağmen ilgili sosyal medya mecrasıyla bağlantı yapılmadığından ilgili kurumun sosyal medya hesabı yok olarak belirtilmiştir. Bazı müftülüklerin ise sosyal medya kanalında yer aldığı ancak paylaşım sayısının olmadığı görülmektedir. Bunun nedeni ise söz konusu tarihte ilgili müftülüğün sosyal medya hesabına ulaşılamamasıdır. Birtakım müftülüklerin web sitelerinde link bulunmasına rağmen bağlantı hatalı ya da çalışmamaktadır. Birçoğunun da merkez teşkilatının ilgili sosyal medya hesaplarına link verdiği tespit edilmiştir.

Müftülüklerin sosyal medyada yer almaması kurumsal kimlik ve kamu iletişimindeki yetersizlik yanında, görevlerini icra ettikleri şehrin halkıyla dinî iletişim sağlamada yetersiz oldukları anlamına da gelebilir.

Başkanlığın organizesinde, “Hadislerle O’nu anlamak” kitabından online sınav yapılarak Türkiye geneli düzenlenen gençlik bilgi yarışması, il müftülükleri içinde, Ankara il Müftülüğünün "Teknolojiyle Eğlen Bilgiyle Öğren” Online Bilgi Yarışması, İstanbul il Müftülüğünün sosyal medyaya da taşınan, içeriği zengin, güncel konulara, güçlü tasarıma sahip, akademik “Din ve Hayat” Dergisi, Ordu il Müftülüğünün sosyal medya üzerinden din hizmeti için henüz yeni kurulan “Dijital TV Stüdyosu” dikkat çeken çalışmalar arasında kendini göstermektedir. 


\subsubsection{Sosyal Medya Paylaşımlarına Dair Bulgular}

Bu bölümde en çok takipçi sayısına sahip 10 il müftülüklerinden nüfusa oranla öne çıkan ilk 5'inin Facebook ve Twitter'daki paylaşım içeriklerine yer verilmiştir.

Tablo 3. Toplam Takipçi Sayısının Nüfusa Oranına Göre Ilk 10 Müftülük

\begin{tabular}{|c|c|c|c|c|c|c|c|c|c|}
\hline $\begin{array}{l}\text { Sira } \\
\text { No }\end{array}$ & Plaka & $\begin{array}{c}\text { Müftülük } \\
\text { Adı }\end{array}$ & il Nüfusu & Facebook & Twitter & Instagram & YouTube & TOPLAM & $\begin{array}{l}\text { Nüfusa } \\
\text { Oran }\end{array}$ \\
\hline 1 & 24 & $\begin{array}{l}\text { Erzincan } \\
\text { İl } \\
\text { Müftülüğüu }\end{array}$ & 234.431 & 11676 & - & - & 539 & 12215 & 0,052 \\
\hline 2 & 53 & $\begin{array}{l}\text { Rize } \\
\text { il } \\
\text { Müftülüğü } \\
\end{array}$ & 344.359 & 11396 & 1998 & 1420 & 951 & 15765 & 0,046 \\
\hline 3 & 55 & $\begin{array}{l}\text { Samsun } \\
\text { ill } \\
\text { Müftülüğüü }\end{array}$ & 1.356 .079 & 22422 & 516 & 1955 & - & 24893 & 0,018 \\
\hline 4 & 26 & $\begin{array}{l}\text { Eskişehir } \\
\text { il } \\
\text { Müftülüğüu }\end{array}$ & 888.828 & 11898 & 557 & - & - & 12455 & 0,014 \\
\hline 5 & 42 & $\begin{array}{l}\text { Konya } \\
\text { ill } \\
\text { Müftülüğüu }\end{array}$ & 2.250 .020 & 17562 & 919 & 4216 & 6.660 & 29357 & 0,013 \\
\hline 6 & 21 & $\begin{array}{l}\text { Diyarbakır } \\
\text { il } \\
\text { Müftülüğüu }\end{array}$ & 1.783 .431 & 13093 & 526 & 1736 & 957 & 16312 & 0,009 \\
\hline 7 & 7 & $\begin{array}{l}\text { Antalya } \\
\text { il } \\
\text { Müftülüğüu }\end{array}$ & 2.548 .308 & 11138 & 543 & - & - & 11681 & 0,005 \\
\hline 8 & 16 & $\begin{array}{l}\text { Bursa } \\
\text { îl } \\
\text { Müftülüğüü }\end{array}$ & 3.101 .833 & 13078 & 1054 & - & - & 14132 & 0,005 \\
\hline 9 & 34 & $\begin{array}{l}\text { İstanbul } \\
\text { il } \\
\text { Müftülüğüü }\end{array}$ & 15.462 .452 & 19932 & 2902 & 6473 & 10900 & 40207 & 0,003 \\
\hline 10 & 6 & $\begin{array}{l}\text { Ankara } \\
\text { ì } \\
\text { Müftülüğüü }\end{array}$ & 5.663 .322 & 9302 & 399 & 1627 & - & 11328 & 0,002 \\
\hline
\end{tabular}

Tablo 3’te görüldüğü gibi, DiB Taşra Teșkilatından il müftülükleri içinde toplam takipçi sayısı nüfusa oranla karşılaștıııldı̆̆ında liderlik Erzincan il Müftülüğüne aittir. Bunu, Rize, Eskişehir, Konya, Diyarbakır il Müftülüğü izlemektedir. Rize, Eskişehir ve Erzincan il Müftülüklerinin nüfusu kendilerinden daha çok olan il müftülüklerine göre toplamda daha çok sosyal medya takipçisine sahip olmalarına bakııırsa, takipçi sayıları ile nüfusun fazla oluşu arasında doğru orantının olmadığı görülmektedir. Müftülüklerin takipçi sayılarının şehir nüfuslarından daha aşağıda olması dikkat çekicidir.

Sosyal medya hesabı olup da takipçi sayısı az olma durumu, "kurumsal bir ilgisizlik yanında, potansiyel olarak sosyal medya sayfasının ilgi çekici olmayan içeriği, hedef kitleye yönlendirilmemiş iletişim tarzı ile açıklanabilir" (Aydın, 2016, s. 209; Sayan, 2021, s. 435). 
Tablo 4. Facebook Takipçi Sayısının Nüfusa Oranına Göre illk 5 Müftülük

\begin{tabular}{|c|c|l|c|c|c|c|}
\hline $\begin{array}{c}\text { Sıra } \\
\text { No }\end{array}$ & Plaka & il Müftülüğü & il Nüfusu & $\begin{array}{l}\text { Başlangıç } \\
\text { Tarihi }\end{array}$ & Facebook & $\begin{array}{c}\text { Nüfusa } \\
\text { Oran }\end{array}$ \\
\hline 1 & 24 & $\begin{array}{l}\text { Erzincan II Müf- } \\
\text { tülüğü }\end{array}$ & 234.431 & 2015 & 11676 & 0,05 \\
\hline 2 & 53 & $\begin{array}{l}\text { Rize İ Müftü- } \\
\text { lüğü }\end{array}$ & 344.359 & 2012 & 11396 & 0,03 \\
\hline 3 & 55 & $\begin{array}{l}\text { Samsun İ Müf- } \\
\text { tülüğü }\end{array}$ & 1.356 .079 & 2015 & 22422 & 0,02 \\
\hline 4 & 26 & $\begin{array}{l}\text { Eskişehir II } \\
\text { Müftülüğü }\end{array}$ & 888.828 & 2012 & 11898 & 0,01 \\
\hline 5 & 42 & $\begin{array}{l}\text { Konya il Müftü- } \\
\text { lüğü }\end{array}$ & 2.250 .020 & 2014 & 17562 & 0,01 \\
\hline
\end{tabular}

Tablo 4'e göre, Facebook kullanan il müftülüklerinden takipçi sayısı nüfusa oranlandığında, sıralamada ilk 5 müftülüğün arasında Erzincan il Müftülüğü birinci sırada yer alırken, Rize il Müftülüğü ikinci Samsun il Müftülüğü üçüncü il müftülüğü olarak tespit edilmiştir.

Facebook kullanımlarında en çok takipçi sayısına sahip Samsun il Müftülüğünün liderliği, takipçi sayısındaki bu başarının il nüfusu ve başlama tarihi ile açıklanamayacağını ortaya koymaktadır.

Facebook'ta, kullanıcıların herhangi bir soru sormadığı tespit edilmiştir. Etkileşimsiz kullanılan hesaplar göze çarpmaktadır.

II müftülüklerinin, Facebook sayfalarındaki paylaşımların içeriklerinin incelenmesi sonucu 3 ana tema bulunmuştur. Aşağıdaki Grafik 1'de ana temalar paylaşım yüzdeleri ile verilmiştir.

Grafik 1. Illk 5 il Müftülüğünün Facebook Paylaşımlarının Ana Temaları

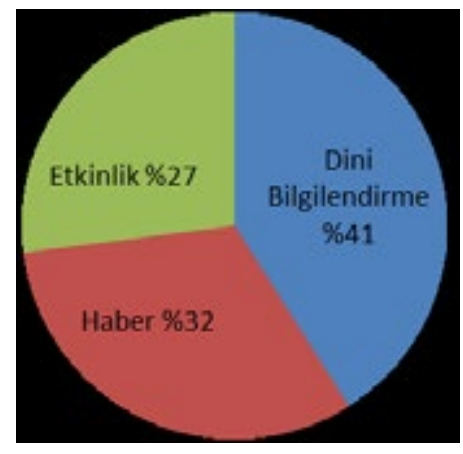

Grafik 1 incelendiğinde, il müftülüklerinin 1244 paylaşımının \%41'inin Dini bilgilendirme çalışmaları ile ilgili olduğu, \%32'sinin Haberlerle ilgili, \%27'sinin Etkinliklerle ilgili olduğu görülmüştür. Aşağıdaki Tablo 5’te, ana temalar, alt temaları ve il müftülüklerine göre paylaşım sayıları ile birlikte verilmektedir. 
Tablo 5. Ilk 5 Il Müftülüğünün Facebook Paylaşım İçerikleri Tablosu

\begin{tabular}{|c|c|c|c|c|c|c|c|}
\hline \multicolumn{2}{|c|}{ Paylaşım İçerikleri } & $\begin{array}{l}\text { Erzincan il } \\
\text { Müftülüğü }\end{array}$ & $\begin{array}{l}\text { Rize II Müf- } \\
\text { tülüğg̈ü }\end{array}$ & $\begin{array}{l}\text { Samsun il } \\
\text { Müftülüğg̈ }\end{array}$ & $\begin{array}{l}\text { Eskişehir il } \\
\text { Müftülüğü }\end{array}$ & $\begin{array}{c}\text { Konya İ } \\
\text { Müftülüğü }\end{array}$ & Toplam \\
\hline \multirow{10}{*}{ 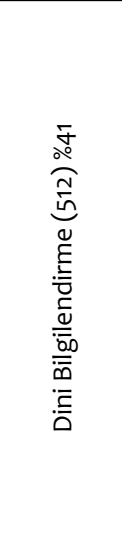 } & $\begin{array}{l}\text { Âyet- } \\
\text { Hadis }\end{array}$ & \multirow[t]{2}{*}{62} & 49 & 22 & - & - & \multirow[t]{2}{*}{185} \\
\hline & Fetvâ & & 30 & 22 & - & - & \\
\hline & Hutbe & 10 & 4 & 2 & - & - & 16 \\
\hline & $\begin{array}{l}\text { Vaaz/Vaaz } \\
\text { Örneği }\end{array}$ & 14 & 1 & 23 & - & - & 38 \\
\hline & Sohbet & & 34 & - & 68 & 25 & 127 \\
\hline & Mukabele & - & 30 & - & 30 & - & 60 \\
\hline & Aşır & - & 30 & - & 1 & - & 31 \\
\hline & Tebrik & 3 & 11 & 5 & 2 & - & 21 \\
\hline & Taziye & - & 2 & 10 & 5 & - & 17 \\
\hline & Duyuru & 4 & 8 & 3 & 1 & 1 & 17 \\
\hline Haber & Başkanlık & 7 & 22 & 18 & 14 & 16 & 77 \\
\hline (392) & Başkan & 5 & 35 & 39 & 42 & 11 & 132 \\
\hline & Müftülük & 11 & 25 & 14 & 6 & 107 & 163 \\
\hline & Yardım & 9 & 11 & - & - & - & 20 \\
\hline Ftkinlik & Başkanlık & 7 & 8 & 2 & 7 & 19 & 43 \\
\hline (340) & Müftülük & 27 & 40 & 69 & 49 & 35 & 220 \\
\hline$\% 27$ & Yardım & 8 & 50 & 2 & 11 & 6 & 77 \\
\hline TOPLAM & $\begin{array}{c}\text { Paylaşım } \\
\text { Sayısı }\end{array}$ & 167 & 390 & 231 & 236 & 220 & 1244 \\
\hline
\end{tabular}

Tablo 5 incelendiğinde, Facebook paylaşımında 1244 paylaşım içinde en çok paylaşım yapan, 390 paylaşım ile Rize ilı Müftülüğü birinci sıradadır.

Dini Bilgilendirme çalıșmaları ana temasının birinci alt teması olan "âyet-hadis-fetva" kapsamındaki paylaşımlar en çok paylaşılan içeriklerdir. Bu paylașımlarda " 1 ayet" șeklinde müstakil paylaşımlar yanında "1 ayet 1 hadis" şeklinde ya da " 1 ayet 1 hadis 1 fetva" şeklinde paylaşımlar yapıldığı tespit edilmiştir.

Sohbet alt temasında, "Ramazan sohbeti”, “iftar tadında”, "Cuma sohbeti”, "Hadis Sohbeti” başlıklarıyla paylaşımlar yapıldığı tespit edilmiştir.

Mukabele ve aşır alt başlıklarında yapılan paylaşımların Ramazan ayıyla sınırlı olduğu görülmüştür. Duyuru alt temasında, Hafızlık, Din Görevlileriyle ilgili sınav duyuruları ve Covid-19 ile ilgili bilgilendirme amaçı duyurular olduğu görülmüştür.

Haber ana temasındaki alt temalardan en çok paylaşım yapılan “Müftülük” alt temasında müftülüklerle ilgili 163 habere yer verilmiştir. Bunlar arasında öne çıkan Konya il Müftülüğünün paylaşımları, yeni göreve başlayan il müftüsüne yapılan "hayırlı olsun” ziyaretleriyle ilgili yapılan paylaşımlardır.

Etkinlik ana teması altında en çok paylaşım yapılan "müftülük" alt temasında yapılan 220 paylaşımda, müftülüklerin aileye, gençlere, kendi personellere yönelik yaptıkları seminer çalışmaları dikkat çekmektedir.

Yardım alt temasında ise, yetim, zekât-fitre, kurban ve Filistin'e yönelik yardım taleplerinin yer aldığı görülmüştür. 
Tablo 6. Twitter Takipçi Sayısının Nüfusa Oranına Göre Illk 5 Müftülük

\begin{tabular}{|c|c|l|r|r|r|r|}
\hline $\begin{array}{c}\text { Sıra } \\
\text { No }\end{array}$ & Plaka & il Müftülüğü & il Nüfusu & $\begin{array}{r}\text { Başlangıç } \\
\text { Tarihi }\end{array}$ & Twitter & Nüfusa Oran \\
\hline 1 & 53 & $\begin{array}{l}\text { Rize } \\
\text { il Müftülüğü }\end{array}$ & 344.359 & 2011 & 1998 & 0,046 \\
\hline 2 & 55 & $\begin{array}{l}\text { Samsun } \\
\text { il Müftülüğü }\end{array}$ & 1.356 .079 & 2014 & 516 & 0,018 \\
\hline 3 & 26 & $\begin{array}{l}\text { Eskişehir } \\
\text { il Müftülüğü }\end{array}$ & 888.828 & 2017 & 557 & 0,014 \\
\hline 4 & 42 & $\begin{array}{l}\text { Konya } \\
\text { il Müftülüğü }\end{array}$ & 2.250 .020 & & 919 & 0,013 \\
\hline 5 & 7 & $\begin{array}{l}\text { Antalya } \\
\text { il Müftülüğü }\end{array}$ & 2.548 .308 & 2018 & & \\
\hline
\end{tabular}

Tablo 6'ya göre, Twitter'da takipçi sayısının, il nüfusuna oranlanmasına göre karşılaştıııldığında müftülükler içinde Rize III Müftülüğü birinci sırada yer alırken, Samsun III Müftülüğü ikinci, Eskişehir il Müftülüğü üçüncü sırada yer almıştır.

Eskişehir ve Konya il Müftülükleri verilerine göre Twitter'da en çok takipçi sayına sahip olmanın Twitter mecrasında daha erken başlama ile doğrudan ilişkisi bulunmamaktadır. Yine Rize ilı Müftülüğünün takipçi sayısına göre Twitter’da başarılı olmanın il nüfusu ile de doğrudan ilişkisi yoktur.

İl müftülüklerinin, Twitter sayfalarındaki paylaşım içeriklerinin incelenmesi sonucu 5 ana tema bulunmuştur. Aşağıdaki Grafik 2'de ana temalar paylaşım yüzdeleri ile verilmiştir.

Grafik 2. İlk 5 il Müftülüğünün Twitter Paylaşımlarının Ana Temaları

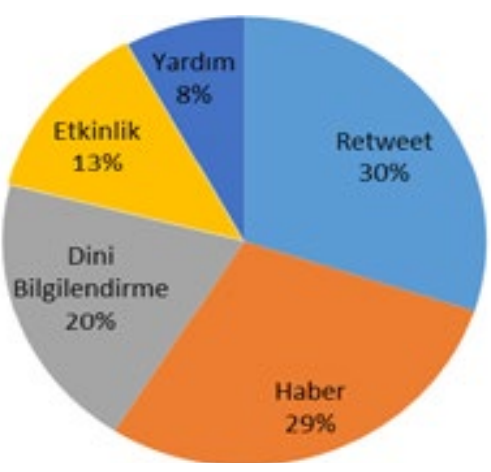

Grafik 2 incelendiğinde, ilk 5 il Müftülüğün 751 paylaşımının \%30'unun Retweet ile ilgili olduğu, \%29'u Haberler, \%20'si Dini bilgilendirme çalışmaları, \%13'ü Etkinlikler ve \%8'inin Yardımlarla ilgili olduğu görülmüştür. Aşağıdaki Tablo 7'de, ana temalar, alt temaları ve îl Müftülüklerine göre paylaşım sayıları ile birlikte verilmektedir. 
Tablo 7. İlk 5 il Müftülüğünün Twitter Paylaşım İçerikleri Tablosu

\begin{tabular}{|c|c|c|c|c|c|c|c|}
\hline \multicolumn{2}{|c|}{ Paylaşım İçerikleri } & $\begin{array}{l}\text { Rize III Müf- } \\
\text { tülüğü }\end{array}$ & $\begin{array}{l}\text { Samsun il } \\
\text { Müftülüğü }\end{array}$ & $\begin{array}{l}\text { Eskişehir il } \\
\text { Müftülüğü }\end{array}$ & $\begin{array}{c}\text { Konya il } \\
\text { Müftülüğü }\end{array}$ & $\begin{array}{l}\text { Antalya il } \\
\text { Müftülüğü }\end{array}$ & Toplam \\
\hline \multirow{8}{*}{ 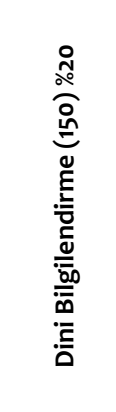 } & Âyet-Hadis & 31 & \multirow{2}{*}{14} & - & 1 & 1 & \multirow{2}{*}{50} \\
\hline & Duâ & 1 & & - & 1 & 1 & \\
\hline & Fetva & 18 & 4 & - & - & - & 22 \\
\hline & Hutbe & 4 & - & - & - & - & 4 \\
\hline & $\begin{array}{l}\text { Sohbet-Va- } \\
\text { az }\end{array}$ & 28 & 11 & - & - & - & 39 \\
\hline & Tebrik & 14 & 2 & - & 1 & 2 & 19 \\
\hline & Taziye & 2 & 1 & - & - & 2 & 5 \\
\hline & Duyuru & 7 & 4 & - & - & - & 11 \\
\hline & Başkanlık & - & 3 & - & - & 1 & 4 \\
\hline $\begin{array}{l}\text { Haber } \\
(218) \% 29\end{array}$ & Müftülük & 23 & - & - & 89 & 75 & 187 \\
\hline & Yardım & 21 & - & 2 & - & 4 & 27 \\
\hline Etkinlik & Başkanlık & 22 & - & 7 & - & 1 & 30 \\
\hline$(100) \% 13$ & Müftülük & 18 & - & 11 & 16 & 25 & 70 \\
\hline & Zekât/Fitre & 6 & - & 12 & 1 & 8 & 27 \\
\hline Yardım & Kurban & 8 & - & - & - & 9 & 17 \\
\hline (59) \%8 & Filistin & 4 & - & - & - & 1 & 5 \\
\hline & Diğer & 10 & - & - & - & & 10 \\
\hline & Başkanlık & 12 & 1 & 15 & 9 & & 37 \\
\hline & Başkan & 13 & 13 & 29 & 18 & & 73 \\
\hline & DiB Haber & 15 & 11 & 22 & 10 & 5 & 63 \\
\hline (RT) & DiB TV & 4 & 4 & 1 & 20 & 1 & 30 \\
\hline & DiB TDV & - & 5 & 3 & 2 & & 10 \\
\hline & Diğer & 4 & 1 & - & 4 & 2 & 11 \\
\hline TOPLAM & $\begin{array}{l}\text { Paylaşım } \\
\text { Sayısı }\end{array}$ & 265 & 74 & 102 & 172 & 138 & 751 \\
\hline
\end{tabular}

Tablo 7’ye göre, Twitter paylaşımında Rize ilı Müftülüğü 265 paylaşımla birinci sıradadır.

Retweet ana temasının alt temalarında en çok paylaşımla "Başkan" alt teması ilk sırada yer alırken, ikinci alt tema olarak "Diyanet TV" yer almaktadır.

Haber ana temasının en çok paylaşım yapılan alt teması olan "Müftülük" alt temasında, müftülüklerin yaptıkları çalışmalarla ilgili haberlere yer verdikleri, yeni göreve başlayan müftülere yapılan "hayırlı olsun" ziyaretlerinin paylaşıldığı tespit edilmiştir. Twitter'da kullanıcılarla etkileşimin çoğunlukla olmadığı görülmektedir. Bir mecrada paylaşılan içeriklerin aynen diğer mecralarda da paylaşıldığı tespit edilmiştir.

\section{Sonuç}

Diyanet İşleri Başkanlığı'nın sosyal medya konusundaki çalışmaları ve Başkanlığın merkez ve taşra teşkilatının (81 il müftülüğünün) sosyal medya kullanım durumları, Facebook ve Twitter paylaşım içerikleri incelenmiştir. Araştırmada, Başkanlığın kamu kurumları içinde sosyal medyayı erken fark eden kurumlar arasında olduğu, yasal mevzuatta ve stratejik planda sosyal medya kullanımıyla ilgili bilgilere yer verdiği, yazııı ve sürekli yayınlarında sosyal medya konusunda çalışmalar yaptığı, dört sosyal medya mecrasında yer aldığı tespit edilmiştir.

Merkez Teşkilatının ise bu gelişime ayak uyduramadığı gözlenirken sadece Başkanlık basın biriminin ve Hac ve Umre Hizmetleri Genel Müdürlüğü'nün sosyal medya hesapları olduğu görülmüştür. Taşra teşkilatı birimlerinden il müftülüklerinin 54'ünün (\%67'sinin) en az bir sosyal medya mecrasında yer aldığı tespit edilmiştir. Beş yıl önce yapılan benzer bir çalışmayla (Aydın, 2016, s. 207) kıyaslandığında bu süreçte sosyal medya kullanan il müftülüklerinin sayısının arttığı, 33 il müftülüğünün daha sosyal medya dünyasına katıldığı görülmüştür. ill müftülüklerinden Facebook kullanan sayısının, 20'den, 49'a; Twitter kullanan sayısının, 9'dan, 
38'e; YouTube kullanan sayısının, 5'ten 27'ye ulaştığı, 23 il müftülüğünün de yeni bir mecra olarak Instagram hesabına sahip olduğu sonucuna ulaşıımıştır. 27 il Müftülüğü (\%33) ise henüz herhangi bir sosyal medya kullanmamaktadır. DiB Başkanlık olarak en çok Facebook, Twitter, YouTube ve Telegram'da yer alırken, il müftülükleri Facebook, Instagram, Twitter ve YouTube'u tercih etmektedirler. Diğer sosyal medya mecralarına pek ilgi gösterilmemiştir.

En çok sosyal medya paylaşımı yapan il Müftülüklerinin nüfusa oranla ilk 5 il Müftülüğünün 13 Nisan 10 Haziran 2021 arası Facebook platformunda yaptığı 1244 paylaşımı analiz edilmiştir. Bu paylaşımların içeriklerinin incelenmesi sonucu 3 ana tema bulunmuştur. 5 il Müftülüğün 1244 paylaşımın \%41'inin Dini bilgilendirme çalışmaları ile ilgili olduğu, \%32'sinin Haberlerle ilgili, \%27'sinin Etkinliklerle ilgili olduğu tespit edilmiştir.

Aynı tarihlerde il Müftülüklerinin Twitter paylaşımları da, analiz edilmiş; 5 ana temaya ulaşılmıştır. 751 Twitter paylaşımının \%30'unun Retweet ile ilgili olduğu, \%29'u Haberler, \%20'si Dini bilgilendirme çalışmaları, \%13'ü Etkinlikler ve \%8'inin Yardımlara ilişkin paylaşımlar olduğu tespit edilmiştir. Bu araştırmada ulaşılan duyurular, etkinlik haberleri, dini içerikli bilgilendirme alt temaları, Gençlik ve Spor Bakanlığı'nın sosyal medya kullanımıyla ilgili yapılan araştırmada ulaşılan alt temalarla benzeşmektedir (Kalfa ve Kocamaz Adaş, 2019, s.17).

Bu temalar, DiB'in misyonu, vizyonu, stratejik hedefleri, yönetmelikleri, sosyal medya kullanımına yönelik teşvik edici çalışmaları ile karşılaştııılıı̆ında, il müftülüklerinin sosyal medya paylaşımlarının örtüştüğü görülmektedir.

il Müftülüklerinin Facebook ve Twitter paylaşımlarındaki benzerlik ve hem Facebook hem de Twitter paylaşımlarında en çok paylaşım yapan il müftülüğü olarak Rize il Müftülüğü dikkat çekmektedir.

Yine çalışmada ulaşılan tespitler ışı̆̆ında, müftülüklerin daha zengin mecraları ve daha zengin içerikleri sosyal medya aracılığıyla paylaşmaları gerektiği, hitap ettikleri kitlelerle daha etkileşimli kullanmaları gereği ortaya çıkmıştır.

Verilen bilgiler ve benzer çalışmalardan da anlaşılacağı gibi sosyal medya, kurumlar ve hedef kitleleri arasındaki iletişimi güçlendiren kurumsal imaj sağlayan bir özelliğe sahiptir. Toplum fertlerinin düşüncelerini almada, görüş, öneri, soru ve sorunlarına kısa sürede ulaşmada bir fırsat olup Başkanlığın ve teşkilatın uygulamalarını daha iyi hâle getirmede de yarar sağlayacaktır. DiB'in sosyal medya aracılığıyla yapacağı paylaşımlar, camdan etkileşimden vatandaş ile ilişkilerini candan hâle dönüştürerek, yakınlaştırmayı sağladığı gibi sahici, samimi birlikteliklere vesile olarak başta gençler olmak üzere her toplum üyesi nezdinde, bireysel ve toplumsal hayata dair doğru dinî bilgilerin erişimini, karşıllıkı kabulü, iyi niyeti geliştirici etki oluşturacak bir zemini de sağlayacağı değerlendirilmektedir.

\section{Öneriler}

Dijital platformların sağladığı fırsatlar kullanılarak Müslümanların araştırarak, okuyarak, sorgulayarak dinî bilgi birikimlerini artırmaları, gündelik ibadet pratiklerini daha sağlıklı şekilde yapmalarına katkı sağlanmalıdır. Türkiye de bulunduğu coğrafyaya hâkim bir ülke olarak DiB üzerinden hem Müslümanlara hem de İslamiyet'i araştıran kullanıcılara yönelik hizmetlerini geliştirerek artırmalıdır (Göksu, 2019, s. 11-40).

Kurumların sosyal medyada yer almaları kadar, kullanımıyla ilgili bir politika geliştirmeleri de etkin olmalarında rol oynayacaktır. Bu konuda devlet politikası olması gerektiği gibi her kurum kendine özgü bir politika da geliştirmelidir. Bu noktada yapılan araştırmalar (Gülaslan, 2018; Gümüş, 2018) doğrultusunda şöyle bir strateji önerilebilir:

- Başkanlık bünyesinde iletişim, her ne kadar birimlerin görevleri arasında yer alsa da, henüz Kurumsal Dinî iletişim ile ilgili bir yönetmelik, çıkmamış olması büyük bir eksikliktir. Bu bağlamda bir yönetmelik ve/veya sosyal medya strateji belgesi/rehberi hazırlanmalı, uygun mecralar, bölgesel farklılıklar, yurt içi-dışı hedef kitleler ve özellikleri tespit edilerek zengin içeriklere yer verilmesi sağlanabilir. Teşkilat bünyesinde özel Sosyal Medya Birimi oluşturulmalı, kurum çalışanları bilgilendirilmelidir. İl müftülükleri bünyesinde hem alana hem konuya hâkim bir Sosyal Medya uzmanı görevlendirilmelidir. Sosyal medya vaizliği yaygınlaştııılmalıdır.

- Her yıl 4 Şevval'de veya anlamlı bir zaman diliminde takipçi sayıları, içerikler incelenerek ölçümler yapılarak, birimlere özel Sosyal Medya Karnesi hazırlanmalı, başarılı uygulamalar iyi örnekler olarak kurum içi ve paydaşlarla paylaşılmalı, başarılı çalışmalar, ekipler, kişiler ödüllendirilmelidir. il/ilçelerin sosyal medya karnesi hazırlanmalı. Atamalarda, yer değiştirmelerde bu kritere de yer verilerek özendirilmelidir. 
- Şehirdeki din eğitimi ortamlarılla ilgili, sahadaki din eğitim-öğretim çalışmalarılla ilgili kısa özgün videolara, fotoğraflara yer verilmesinin, takipçilerin dikkatini çekeceği dinî iletişimi ve din eğitimini güçlendireceği düşünülmektedir.

- Sosyal medyada en çok takipçiye sahip il müftülükleri ile sosyal medyada yer almayan il müftülüklerine yönelik araştırmalar yapılabilir.

- Başkanlığın diğer birimlerinin sosyal medya mecralarındaki durumu, il müftülüklerinin Facebook ve Twitter dışındaki sosyal medya paylaşımları içerik analizi yapılarak karşılaştırılabilir. Farklı pozisyonlarda görevli din görevlilerinin sosyal medya kullanımları araştırılabilir.

- Kamuoyunun DiB'in sosyal medya kullanımıyla ilgili görüşleri araştırılarak elde edilecek verilerle Başkanlığın sosyal medya kullanımı zenginleştirilebilir.

\section{Son Notlar}

1 Buradaki dikey iletişimle, yaratıcı ve üst otorite olarak Allah'la, kul olan insan arasındaki yaratııı-kul ilişkisi; yatay iletişimle aynı varlık kategorisinde olan insanların birbirleriyle iletişimi kast edilmektedir. Zira kişilerarası iletişim çalışmalarına göre, insanlar arasında da hem yatay hem de farklı statüler sebebiyle hiyerarşik olarak dikey iletişim kurulabilir.

\section{Kaynakça}

Ak, Z. (1992). Türkiye radyolarında dini yayınlar. Diyanet Aylık Dergi, (14) 21-26.

Akyön, S. (2016). Türkiye'de dini yayıncılığın gelişimi: Dini radyolar (Yüksek Lisans Tezi). Erişim Adresi: http:// tez.yok.gov.tr (Tez No: 437364).

Appell, V. S. (Ed.). (2012). Social media policy workbook for jewish organizations. Erişim Adresi: https://www. reconstructingjudaism.org/sites/default/files/darim-workbook_social_media.pdf

Aşlamacı, i. (2016). Üniversite öğrencilerinin Diyanet İşleri Başkanlığı hizmetlerine yönelim durumları. İnsan ve Toplum Bilimleri Araştırmaları Dergisi, 5(6), 1563-82.

Aydın, H. ve Eken, M. (2014). Din görevlilerinin sosyal medya kullanım alışkanlıkları. İçinde M. Çamdereli, B. Önay Doğan ve N. Kocabay Şener (Ed.), Medya ve din (1. basım, ss. 377-405). Cağaloğlu, ỉstanbul: Köprü Kitapları

Aydın, H. (2016). Diyanet iş̧leri Başkanlığı merkez ve taşra teşkilatının sosyal medya kullanımı üzerine bir inceleme. e-Journal of New World Sciences Academy, 11(3), 203-12. doi: 10.12739/NWSA.2016.11.3.4C0211.

Aydın, Ö. (2019). Diyanet İşleri Başkanlığı̆'nın hukuki statüsü üzerine tartışmalar. Akademik incelemeler Dergisi, 14(2), 239-76.

Batar, Y. (2020). illetişim modelleri ışı̆̆ında dini iletişimin doğası. Mesned ilahiyat Araştırmaları Dergisi, 11(2), 417-39.

Certel, H. (2008). Din-iletişim ilişkisi ve dinî iletişim engelleri. Süleyman Demirel Üniversitesi Ilahiyat Fakültesi Dergisi, 2(21), 127-58.

Connor, M. J. O., Ferrarı-Toniolo, A. (1971). ‘Communio et progressio’ On the means of social communication written by order of the second Vatican council". Erişim Adresi: http://www.vatican.va/roman_curia/ pontifical_councils/pccs/documents/rc_pc_pccs_doc_23051971_communio_en.html\#Nota\%207.

Conrad, A. (2018). 10 powerful church statistics on social media use. Geliş tarihi (https://blog.capterra.com/ church-statistics-social-media/).

Cresswell, John W. (2017). Eğitim araştırmaları. İstanbul: Edam Yayınları.

Curley. (2011). Reginald Aubrey Fessenden. Encyclopaedia Britannica. Erişim Adresi: https://www.britannica. com/biography/Reginald-Aubrey-Fessenden

Çuhadar, M., (Ed.). (2015). Dijitalleşen din ve diyanet. içinde M. Çamdereli, B. Önay Doğan ve N. Kocabay Şener (Ed.) Dijitalleşen Din (Medya ve Din 2). İstanbul: Köprü Yayınları.

Çuhadar, M. (2019). Türkiye'de kamu hizmeti yayıncılığı açısından dinî temalı TV programları ve Diyanet TV program türleri üzerine bir inceleme. Medya ve Din Araștırmaları Dergisi (MEDIAD), 2(2), 237-66. 
DiB Genelge. (2020). Diyanet İşleri Başkanlığı din hizmetleri genel müdürlüğü uygulama genelgesi. Erişim Adresi: https://hukukmusavirligi.diyanet.gov.tr/Documents/Din\%20Hizmetleri\%20Genel\%20M\%C3\%BCd\%C3\%BC rl\%C3\%BC\%C4\%9F\%C3\%BC\%2oUygulama\%20Genelgesi.pdf

DiB Haber. (2012). Diyanet sosyal medyada. Erişim Adresi: https://diyanet.gov.tr/tr-TR/Kurumsal/Detay/514/ diyanet-sosyal-medyada

DiB Haber1. (2012). Sosyal medyada hadis dersleri. Erişim Adresi: https://diyanet.gov.tr/tr-TR/Kurumsal/ Detay/518/sosyal-medyada-hadis-dersleri

DiB Haber2. (2019). Sosyal medyayı hayırlı yolda kullanmalıyız. Erişim Adresi: https://diyanet.gov.tr/tr-TR/ Kurumsal/Detay/25644/sosyal-medyayi-hayirli-yolda-kullanmaliyiz

DiB Haber3. (2020). Vatandaşlarımızı Kur'an-ı Kerim'in huzur veren tilaveti ve mesajlarıyla buluşmaya davet ediyorum. Erişim Adresi: https://diyanet.gov.tr/tr-TR/Kurumsal/Detay/30077/vatandaslarimizi-kuran-ikerimin-huzur-veren-tilaveti-ve-mesajlariyla-bulusmaya-davet-ediyorum

DiB Haber4. (2021). Sosyal medyada bir yalanı binlerce kişinin beğeniyor olması, şifa aramamız gereken kötü bir hastalık. Erişim Adresi: https://diyanet.gov.tr/tr-TR/Kurumsal/Detay/32326/sosyal-medyada-bir-yalanibinlerce-kisinin-begeniyor-olmasi-sifa-aramamiz-gereken-kotu-bir-hastalik

DiB Hutbe. (2020). Teknoloji bağımlılığı ve sosyal medya ahlakı. Erişim Adresi: https://diyanet.gov.tr/tr-TR/ Kurumsal/Detay/26261/cuma-hutbesi-teknoloji-bagimliligi-ve-sosyal-medya-ahlaki

DiB Kanun. (1965). Diyanet İşleri Başkanlığı Kuruluş ve Görevleri Hakkında Kanun. C. 633. Erişim Adresi: https:// www.mevzuat.gov.tr/MevzuatMetin/1.5.633.pdf

DiB 2021 Performans Programı. (2021, 24 Mayıs). Erişim adresi: http://www.sp.gov.tr/upload/xSPRapor/ files/8QnoC+DIB.pdf

DiB SP. (2020). DiB Stratejik Plan. Erişim Adresi: http://www.sp.gov.tr/tr/kurum/s/155/Diyanet+Isleri+Baskanligi

Dinler, Z. (1998). Bilimsel araştırma ve internete bağlı bilgi merkezleri el kitabı. Bursa: Ekin Kitapevi Yayınları.

EJP. (2010). U.S. Synagogues lag in use of web and social media technologies. Erişim Adresi: https:// ejewishphilanthropy.com/u-s-synagogues-lag-in-use-of-web-and-social-media-technologies/

Erdoğan, M. (2020). Kuruluşunun 96. yılında Diyanet İşleri Başkanlığı. Yörünge Dergisi. Erişim Adresi: https:// www.yorungedergi.com/2020/03/kurulusunun-96-yilinda-diyanet-isleri-baskanligi/

Göksu, O. (2019). Dinin dijitalleşmesi: Dinin iletişiminde ve öğretilmesinde kullanılan dijital araçlar bağlamında Diyanet İșleri Başkanlığı ve Çay House örnekleri. içinde Göksu, O. (Ed.) iletişimin Dijital Boyutu. Konya: Literatürk Academia.

Gur Media. (t.y.) Dünyanın ilk Kur’an-ı Kerim kaydını yapan kişi bir Hollandalı. Erişim Adresi: https://gurmedia.nl/ dunyanin-ilk-kuran-kerim-kaydini-yapan-kisi-bir-hollandali/

Gülaslan, T. (2018). Kamu yönetiminde sosyal medya kullanımı ve Yönetimi: Temel ilkeler ve öneriler. (Yüksek Lisans Tezi). Erişim Adresi: http://tez.yok.gov.tr (Tez No: 508898).

Gümüş, N. (2018). Sosyal medyanın kamu kurumları tarafından kamusal pazarlama aracı olarak kullanılması: 81 il valiliği üzerinde bir araştırma. Abant İzzet Baysal Üniversitesi Sosyal Bilimler Enstitüsü Dergisi, 18(4), 189-212. doi: 10.11616/asbed.v18i41997.505870.

Haberli, M. (2013). Dinlerin internet ortamındaki temsili ve dağılımı. The Journal of Academic Social Science Studies, 6(1), 859-73.

Hamidullah, M. (1407). el-vesâikü's-siyâsiyye li'l-ahdi'n-nebevî ve'I-hilâfeti'r-râşide. 6. bs. Beyrut: Daru'n-Nefais.

Hökelekli, H. (2006). Günümüz iletişim teknikleri ve dinî iletişim. Diyanet IIlmi Dergi, 42(1 Ocak-Şubat-Mart), 41-58.

İrk, E. (2015). Internet kullanımının ergenlerin dini gelişimine etkisi. (Yüksek Lisans Tezi). Erişim Adresi: http:// tez.yok.gov.tr (Tez No: 427449).

Kalfa, M. ve Kocamaz Adaş, S. (2019). Sosyal medyayı kullanım açısından Gençlik ve Spor Bakanlığının analizi. Türk Spor Bilimleri Dergisi, 2(1), 6-21. 
Koç, A. (2011). Din eğitiminde etkili iletişim. İstanbul: Rağbet Yayınları.

Lewis, B. (2017). How social media is changing the church. Erişim Adresi: https://theconversation.com/howsocial-media-is-changing-the-church-57405

Menekșe, Ö. (2015). Dinin dijitalleşmesi ve mobil uygulamalar. içinde M. Çamdereli, B. Önay Doğan ve N. Kocabay Şener (Ed.) Dijitalleşen Din (Medya ve Din 2). İstanbul: Köprü Yayınları.

en-Neysâbûrî, H. (ts.) el-Müstedrek. Beyrut: Daru'l-Kütübi'l-ilmiyye.

O’Neal, J. E. (2006). Fessenden: World's first broadcaster? Erişim Adresi: https://www.radioworld.com/newsand-business/fessenden-worlds-first-broadcaster

Patton, M. Q. 2014. Nitel araştırma ve değerlendirme yöntemleri (M. Bütün, S. B. Demir Çev). Ankara: Pegem Akademi.

Pew Research Center. (2015). The future of world religions: Population growth projections, 2010-2050. Washington. Erişim Adresi: https://www.pewforum.org/2015/04/02/religious-projections-2010-2050/

Sayan, Y. E. (2021). Türkiye'de yüksek din öğretimi kurumları adına sosyal medya kullanımı ve fakültelerin sosyal medya stratejilerinin incelenmesi. Dinbilimleri Akademik Araştırma Dergisi, 21(1),415-49. doi: $10.33415 /$ daad.820746.

Subaşı, N. (2005). Türk modernleşmesinde dinsel bir deneyim -Diyanet işleri Başkanlığı"”. İslâmiyat, 8(4), 7982.

Subaşı, N. (2017). Diyanet ve örgütlü dinî yapı ve cemaatler. İnsan ve Toplum, 7(1), 223-32. doi: 10.12658/human. society.7.13.Roozo.

Tocci, M. (2018). Tips for making the most of your church social media pages. Erişim Adresi: https://simpletexting. com/tips-for-making-the-most-of-your-church-social-media-pages/

TÜiK. (t.y.). TÜiK sosyal medya takipçileri için kullanım ilkeleri. Erişim Adresi:https://tuikweb.tuik.gov.tr/jsp/ duyuru/upload/sm_kul_ilke_tr.pdf

TÜiK 2015. (2015). TÜIK dini yayın süresi. Erişim Adresi: https://data.tuik.gov.tr/Bulten/DownloadlstatistikselTa blo?p=ueKnrU6GG6sRz19Rw3JNCoxhHK83XjVfCa40K5XzRfc9/OpcHcuJSloKN9vS7aMv

TÜiK 2020. (2020). Kurumlarla internetli iletişim. Hanehalkı BT Kullanım. Erişim Adresi: https://data.tuik.gov.tr/ Bulten/Index?p=Hanehalki-Bilisim-Teknolojileri-(BT)-Kullanim-Arastirmasi-2020-33679

Vardi, R. (2012). Internet ve İslam: Din sosyolojisi açısından dini siteler üzerine bir araștırma. (Doktora Tezi). Erişim Adresi: http://tez.yok.gov.tr (Tez No: 317383).

wearesocial, Ocak 2021. (2021). Digital 2021. Erişim Adresi: https://wearesocial.com/uk/blog/2021/01/digital2021-the-latest-insights-into-the-state-of-digital

wearesocial, Ocak 2021 Turkey. (2021). Digital-2021-turkey. Erişim Adresi: https://datareportal.com/reports/ digital-2021-turkey

wearesocial, Nisan 2021. (2021). Digital-2021-the-latest-insights-into-the-state-of-digital. Erişim Adresi: https:// wearesocial.com/uk/blog/2021/01/digital-2021-the-latest-insights-into-the-state-of-digital 


\title{
MEDIAD
}

\section{Social Media Usage Level of the Presidency of Religious Affairs: A Research in the Context of Central and Provincial Organizations}

\author{
Yunus Emre SAYAN
}

\section{Extended Abstract}

According to the Islamic education perspective, the religious communication process that started with Allah speaking with the spirits He would create, the first human and the first Islamic Prophet He continued verbally at the beginning with his conversation with Adam, then continued in written form by adding pages and books. With the envoys of mercy named "prophet, messenger", Allah's messages regulating life were conveyed to people. Man's understanding about life, himself, his environment, and the first information about life became possible through communication in this sense, family life, politics, trade, education, etc. All of his relationships that add meaning to his life have been shaped by processes based on communication. The command to convey the religion at this point, also stating the strategies of Allah, played a major role in the continuity of religious communication; This spreading system, the first ring of which was formed by the prophets, continued to live with the efforts of other believers included in the ring and will continue until the Day of Judgment in a wide range to include both its members and other people.

After the death of the Last Messenger of Islam, this communication process continues based on his relics and the communication between people. In the following years, different worldviews, from the point of view of today's scientific disciplines, have taken their share from the distinctions that separate and/or classify religion in life, and have been the subject of investigations as a separate field of communication with the title of religious communication. Religious education - training and guidance services started face to face and continued with different tools from the past to the present by using the developing written, audio and visual tools. The four basic elements of communication; From source - message - tool/channel and receiver, the tool/channel part has continued its course by developing in parallel with the developments in other communication tools and technologies.

In the new era, which is characterized as the information age, the means of access to information and communication have also been enriched, and digital tools and social media have become prominent. In this change; individuals quickly adapt to new communication tools; but the institutions react differently, while some institutions experience a change in every field, there are those which have not yet grasped the importance of the subject.

New media, including social media, also contain religious information and content, and many religious communities, groups, and institutions in the world continue to seek to find a place for themselves in these new channels. Despite the strategies put forward by Christian and Jewish-centered religious institutions on social media, the scarcity of studies in the literature on social media interest of institutions representing Islam draws attention.

This study aims to analyze the situation of the Presidency of Religious Affairs (PRA), which has an important mission in our country, especially in the context of non-formal religious education, against the new media, and to analyze the use of social media while performing its duty to provide religious services to the public in central and provincial organizations, in quantitative and qualitative terms with the current situation and lastly to share the results of detailed research on this subject.

The PRA's interest in new media, which should carry out both institutional communication as an official state institution and religious communication together with its duty of providing religious information, is valuable. It is also a matter of curiosity how the change in communication channels in our country took place in the eyes of PRA, in parallel with the worldwide digital transformation, especially after Covid-19, which took 
place worldwide in December 2019. The official websites of the institution and its units were examined and it was determined which social media channels they used, and the prominent units and their posts in these channels were subjected to content analysis. In addition to quantitative data, social media issues from the online and printed publications of the institution were examined with the documentation method.

According to the research findings; It has been understood that PRA is one of the first state institutions to enter social media in Turkey. It has been determined that it has included studies that will raise awareness in the context of institutional and religious communication in the historical process, and that he has made rich studies that will inform the public with oral, written, visual and auditory publications. It has been determined in the research that only the Presidency unit and the General Directorate of Hajj Services use social media accounts in the central organization and that the Provincial Mufti's use of social media has made a certain improvement compared to previous years in the provincial organization. It was understood in the research that $67 \%$ of the Provincial Muftis had an institutional preference to be present in social media. While this preference mainly focuses on Facebook in parallel with the usage in the world, it is followed by Twitter, YouTube, and Instagram, respectively. While 17 Provincial Mufti (21\%) are involved in all four social media channels at the same time, 27 Provincial Mufti (33\%) still do not prefer the use of social media. When considered in terms of corporate integrity, no unit should stay away from social media. It is considered that creating a separate unit by preparing a social media regulation within the institution will increase awareness.

In this context, it will be useful to provide support to the units that do not use social media and to make them use social media as soon as possible.

\section{Araştırmacıların Katkı Oranı Beyanı/ Contribution of Authors}

Araştırma tek bir yazar tarafından yürütülmüştür.

The research was conducted by a single author.

$* * * * * * * *$

\section{Çıkar Çatışması Beyanı / Conflict of Interest}

Çalışma kapsamında herhangi bir kurum veya kişi ile çıkar çatışması bulunmamaktadır.

There is no conflict of interest with any institution or person within the scope of the study.

$* * * * * * * *$

Intihal Politikası Beyanı / Plagiarism Policy

Bu makale iThenticate yazııımıyla taranmıştır. Intihal tespit edilmemiştir.

This article has been scanned by iThenticate. No plagiarism was detected.

$* * * * * * * *$

\section{Bilimsel Araștırma ve Yayın Etiği Beyanı / Scientific Research and Publication Ethics Statement}

Bu çalışmada "Yükseköğretim Kurumları Bilimsel Araştırma ve Yayın Etiği Yönergesi" kapsamında uyulması belirtilen kurallara uyulmuştur.

In this study, the rules stated in the "Higher Education Institutions Scientific Research and Publication Ethics Directive" were followed 